\author{
MARIAN DYGO \\ Wydziat Historyczny Akademii \\ Humanistycznej im. A. Gieysztora \\ Instytut Historyczny \\ Uniwersytetu Warszawskiego
}

\title{
CZY ISTNIAE FEUDALIZM W EUROPIE ŚRODKOWO-WSCHODNIEJ W ŚREDNIOWIECZU?
}

I

Na tytułowe pytanie znajdziemy w literaturze przedmiotu przeciwstawne odpowiedzi. Zdaniem Jenő Szűcsa elementy feudalizmu, rozumianego jako „system lenny”, pojawiły się w naszej części Europy po 1200 r. Istniały one tutaj niedługo i do tego w „formie skondensowanej”, toteż struktury feudalne były „«okrojone» lub szczątkowe, kiedy indziej zaś nierozwinięte i hybrydalne". Promotorami feudalizacji byli władcy ${ }^{1}$. Natomiast Gottfried Schramm ostro przeciwstawia feudalną (w znaczeniu wasalno-lennym) Europę Zachodnią niefeudalnej Europie Środkowo-Wschodniej: „W Polsce i na Węgrzech nie było wyraźnej epoki lennej. $\mathrm{Ba}$, nawet w Czechach lennictwo było mniej rozwinięte niż gdzie indziej w Europie Środkowej i Zachodniej"2. Z kolei Robert Bartlett włącza Polskę (tak samo jak Europę Środkowo-Wschodnią) do świata feudalnego, „którego część stanowiła”. Pojęciem feudalizmu obejmuje dwie instytucje: lenno oraz władztwo gruntowe. Rozprzestrzenianie się feudalizmu miało być konsekwencją „średniowiecznego kolonializmu” rozumianego jako proces transferu na peryferie Zachodu skodyfikowanych form życia społecznego, „które łatwo się przenosiły i adaptowały, a zarazem

${ }^{1}$ J. Szűcs, Trzy Europy, Lublin 1995 (tł. z wyd. franc. 1985, oryg. węg. 1981), s. 64-65. Anonimowym Recenzentom polskiemu i czeskim dziękuję za uwagi krytyczne oraz podpowiedzi bibliograficzne.

${ }^{2}$ „In Polen und Ungarn fehlte eine ausgesprochene Lehensperiode. Ja, selbst in Böhmen war das Lehenswesen weniger entfaltet als sonst in Mittel- und Westeuropa", G. Schramm, Polen - Böhmen - Ungarn: Übernationale Gemeinsamkeiten in der politischen Kultur des späten Mittelalters und der frühen Neuzeit, PH 76, 1985, 3, s. 424 (przekładu cytatów z publikacji obcojęzycznych dokonał autor artykułu). 
były odporne na czynniki zewnętrzne"3. Natomiast Karol Modzelewski wyraża pogląd, że w Europie Środkowo-Wschodniej nie było feudalizmu w znaczeniu instytucji wasalstwa lennego. Na przeszkodzie recepcji feudalizmu lennego miał stać „,barbarzyński kolektywizm”. Natomiast ten kolektywizm od XIII w. nie powstrzymał rozwoju feudalnego władztwa gruntowego, które w późnym średniowieczu zdominowało tutaj strukturę agrarną. Promotorem takiego feudalizmu był Kościół $1^{4}$. Wreszcie zdaniem Jánosa M. Baka termin feudalizm nie jest odpowiedni w odniesieniu do Europy Środkowo-Wschodniej, ponieważ poza nielicznymi wyjątkami „nie było na tym obszarze zależności feudalnych, jakkolwiek definiowanych i jakkolwiek stosownie do tego opisywanych" ${ }^{5}$. Uwaga autora koncentruje się na feudalizmie wasalno-lennym.

Referując powyższe poglądy, wywołaliśmy kwestię rozumienia terminu feudalizm w historiografii. Chris Wickham zaproponował ostatnio następującą systematyzację: 1) feudalny sposób produkcji à la Karol Marks; 2) społeczeństwo feudalne à la Marc Bloch; 3) feudalne stosunki prawne à la Heinrich Mitteis/François Louis Ganshof ${ }^{6}$. To zestawienie chętnie uzupełnimy o 4) mentalność feudalną à la Georges Duby ${ }^{7}$. Oczywista jest duża umowność tej systematyzacji. W naszych rozważaniach skupiamy się na feudalizmie w trzecim znaczeniu przy uwzględnieniu pewnych aspektów feudalizmu w znaczeniach drugim i czwartym.

Poza polem naszej obserwacji pozostawiamy w zasadzie feudalizm w znaczeniu pierwszym. Tymczasem władztwo gruntowe bywa - jak widzieliśmy - interpretowane jako jeden z przejawów (obok lenna) lub jako jedyny przejaw feudalizacji Europy Środkowo-Wschodniej. Zagadnienie relacji między lennem i władztwem gruntowym zasługuje niewątpliwie na uwagę. Oliver Auge proponuje ostatnio mediewistom niemieckim, aby rozstać się z tradycyjnym pojęciem „lennictwa” i przywrócić do

${ }^{3}$ R. Bartlett, Tworzenie Europy. Podbój, kolonizacja i przemiany kulturowe 950-1350, Poznań 2003 (oryg. ang. 1993), s. 9 („Wstęp do wydania polskiego”), 455.

${ }^{4}$ K. Modzelewski, Barbarzyńska Europa, Warszawa 2004, s. 453-454; syntetycznie o władztwie gruntowym jako nośniku feudalizacji w naszej części Europy zob.także idem, The System of the Ius Ducale and the Idea of Feudalism, „Quaestiones Medii Aevi” 1, 1977, s. 71-99, zwł. s. 75-76, 86, 93, 97.

${ }^{5}$ „gab es keine, nach welcher Definition auch immer beschreibbaren feudalen Abhängigkeiten in diesem Raum", J. M. Bak, Probleme einer vergleichenden Betrachtung mittelalterlicher Eliten in Osteuropa, w: Das europäische Mittelalter im Spannungsbogen des Vergleichs. Zwanzig internationale Beiträge zu Praxis, Problemen und Perspektiven der historischen Komparatistik, wyd. M. Borgolte, Berlin 2001, s. 60.

${ }^{6} \mathrm{Ch}$. Wickham, Le forme del feudalesimo, w: Il feudalesimo nell'alto medioevo, t. 1, Spoleto 2000 , s. $15-46$.

${ }^{7}$ G. Duby, La féodalité? Une mentalité médiévale, „Annales. Économies, Sociétés, Civilisation" 13, 1958, 4, s. 765-771. 
życia pojęcie feudalizmu, dzięki czemu da się „przerzucić terminologiczny pomost do badań zachodnioeuropejskich oraz równocześnie połączyć zjawiska lennictwa i władztwa gruntowego, które w Niemczech są traktowane prawie zawsze rozłącznie"8. Z kolei Brigitte Kasten wyraża pogląd, że nie ma fundamentalnej różnicy między władztwem gruntowym i władztwem lennym. Obie struktury umieszcza zresztą w ramach większej całości, określanej (za Wilhelmem Ebelem) słowem Leihe, oznaczającym przenoszenie delegowanych uprawnień, np. do dzierżenia ziemi w różnych formach (prekaria, beneficjum, lenno itd.). Zgodnie z tym tokiem rozumowania lenno byłoby w istocie zjawiskiem przynależnym przede wszystkim do świata gospodarki ${ }^{9}$.

Fakt, że istniały w Europie obszary, na których przyjęło się władztwo gruntowe, ale nie doszło do recepcji lenna rycerskiego, każe zachować spory dystans wobec wywodów cytowanej autorki. Raczej nasuwa się myśl, że obie te instytucje były zasadniczo odmienne. Nad naturą owej odmienności przyjdzie nam zastanowić się w trakcie dalszych wywodów.

Jak wiadomo, w ostatnich dwóch dekadach doszło do daleko idącej rewizji obiegowych poglądów na temat feudalizmu w Europie Zachodniej obecnych w literaturze przedmiotu. Jeszcze w 1990 r. Alain Guerreau twierdził, że określanie mianem feudalizmu (tylko) stosunków wasalno-lennych prowadzi historiografię na manowce, i wskazywał na potrzebę opracowania teorii feudalizmu w jego całej złożoności ${ }^{10}$. Tymczasem już cztery lata później ukazało się nowatorskie dzieło Susan Reynolds o „lennach i wasalach”

8 „eine terminologische Brücke zur westeuropäischen Forschung zu schlagen und zugleich die in Deutschland fast immer getrennt voneinander behandelten Phänomene Lehnswesens und Grundherrschaft zusammenzuführen", o. Auge, Ausbildung und Verbreitung des Lehnswesens im Reich und in Italien im 12. und 13. Jahrhunderteine Zusammenfassung, w: Ausbildung und Verbreitung des Lehnswesens im Reich und in Italien im 12. und 13. Jahrhundert, red. K.-H. Spieß, Ostfildern 2013, s. 337-355, tutaj s. 355.

${ }^{9}$ B. Kasten, Zum Gedankengut der Fürstenerhebungen im 12. und 13. Jahrhundert, w: Ausbildung und Verbreitung des Lehnswesens, s. 160-186, zwł. s. 159, 168-172, 184-186.

${ }^{10}$ A. Guerreau, Fief, féodalité, féodalisme. Enjeux sociaux et réflexion historienne, „Annales. Économies, Sociétés, Civilisation” 45, 1990, 1, s. 137-166. Już wcześniej zaprezentował się on jako teoretyk feudalizmu - „systemu” IV-XIX w. - A. Guerreau, Le féodalisme. Un horizon théorique, Paris 1980. W najnowszej jego książce, o mediewistyce przyszłości, problem feudalizmu jako paradygmatu badawczego został pominięty A. Guerreau, L'Avenir d'un passé incertain. Quelle histoire du Moyen Âge au XXI' siècle?, Paris 2001; por. jednak tegoż: À la recherche de la cohérence globale et de la logique dominante de l'Europe féodale, w: Die Gegenwart des Feudalismus - Présence du féodalisme et présent de la féodalité - The Presence of Feudalism, red. N. Fryde i in., Göttingen 2002, s. 195-210. 
na średniowiecznym Zachodzie ${ }^{11}$. Nie da się przejść nad nim do porządku dziennego, podejmując studia nad feudalizmem bodajże w każdym z wyróżnionych przez Ch. Wickhama znaczeniu.

S. Reynolds postawiła pod znakiem zapytania zasadność traktowania w historiografii terminów: wasal, lenno, feudalizm jako kluczowych dla opisu, analizy i zrozumienia epoki średniowiecza: „Lenna i wasalstwo, tak jak są dzisiaj powszechnie rozumiane przez mediewistów, są koncepcjami postśredniowiecznymi, jakkolwiek raczej wcześniejszymi niż koncepcja feudalizmu" ${ }^{\prime 2}$. Mianowicie terminy te są dziełem wczesnonowożytnych prawników, którzy przy okazji studiowania prawa rzymskiego zainteresowali się akademickim prawem lennym, opartym z kolei na północnowłoskim zbiorze prawniczym Libri (Consuetudines) feudorum z XII/XIII w. W tym zbiorze mówi się o prawie własności określanym jako feudum (= lenno), którego posiadacze nazywali się wasalami. Inna sprawa, powiada Reynolds, że słowo lenno (= feudum, feodum itp.) miało wiele znaczeń; tym bardziej wieloznaczne było poprzedzające go chronologicznie słowo beneficium. Podobnie miała się rzecz ze słowem wasal: „W koncepcji wasalstwa [--] skrywa się co najmniej pół tuzina różnych typów relacji, które należy odróżniać" ${ }^{13}$.Zdaniem S. Reynolds wiązanie wasalstwa z lennem nie ma uzasadnienia. Na dodatek do XII-XIII w. granice między poszczególnymi grupami społecznymi były płynne: „Społeczeństwo średniowieczne na większości obszarów i przez większość czasu przedstawiało się jako złożone raczej z niezliczonych stopni lub warstw niż z szerokich społecznych przepaści”" . Jeśli zaś chodzi o prawa własności, to „Przed wiekiem XII ludzie wolni oczekiwali, że będą dzierżyć swoją ziemię jako [- - ] pełną własność: to znaczy, oni dzierżyli ją w sposób, który przedstawiali sobie jako pełne prawa, bez względu na jakiekolwiek powinności, które ich obowiązywały"15.

11 S. Reynolds, Fiefs and Vassals. The Medieval Evidence Reinterpreted, Oxford 1994; wydanie polskie S. Reynolds, Lenna i wasale. Reinterpretacja średniowiecznych źródeł, Kęty 2001, oparte jest na zbyt swobodnym przekładzie, dlatego odwołujemy się do wydania oryginalnego.

12 „Fiefs and vassalage, as they are generally defined by medieval historians today, are post-medieval constructs, though rather earlier than the construct of feudalism", eadem, Fiefs and Vassals, s. 2.

${ }^{13}$,The concept of vassalage $[--]$ conceals at least half a dozen different types of relation that need to be distinguished", ibidem, s. 33 .

14 „Medieval society in most areas and at most times looks like one of infinite gradations or layers rather than one of wide social gulfs", ibidem, s. 39 n.

15 „Before the twelfth century free men expected to hold their land as [- - ] full property: that is, they held it with what, irrespective of any obligations they owed, they thought of as full rights", ibidem, s. 59. 
Jak według S. Reynolds doszło do ukształtowania się lenna? Aż do XII w. słowo lenno nie oznaczało dokładnie zdefiniowanej kategorii własności zie$\mathrm{mi}$, z określonymi zobowiązaniami. W istocie nie było wówczas własności o charakterze warunkowym. Zresztą do końca XII w. nadań lennych nie było wiele. Dopiero w XIII w. słowo lenno zaczęło robić karierę, w czym odzwierciedlał się rozwój prawa własności. Te przemiany były konsekwencją biurokratyzacji administracji publicznej, posługującej się nowym profesjonalnym prawem, oraz pojawienia się zastępów prawników po uniwersytetach. Władcy przekształcali alodia w lenna, na lenników zaś nakładali nowe powinności, jednak z reguły bez większego ograniczenia ich uprawnień majątkowych: „wydaje się, że chodziło o zapewnienie jakiegoś narzędzia do politycznego podporządkowania nowych lenników, co często symbolizowano poprzez przysięgi i pewnego rodzaju ceremonię hołdu. [- - ] W tym czasie zaczynają pojawiać się, o ile w ogóle są dostrzegalne, konceptualizacje czegoś w rodzaju «piramidy feudalnej» lub «hierarchii praw posiadania ziemi», tak jak one są rozumiane dzisiaj" ${ }^{16}$.Zatem lenna i wasale pojawiają się paralelnie do rozwoju królestw opartych na sprawnej administracji i fachowym aparacie urzędniczym.

S. Reynolds poświęca dużo uwagi związkowi między lennem i szlachectwem. Jej zdaniem przed XII w. wasale otrzymujący lenna „przypuszczalnie wkraczali na drogę prowadzącą do szlachectwa, jakkolwiek luźno pojmowanego" ${ }^{17}$; miało to związek z płynnymi wówczas granicami społecznymi, które uniemożliwiały zdefiniowanie szlachectwa. Natomiast w XII w. prawnicy połączyli własność lenną z godnością szlachecką: „Z pewnością to nie przypadek, że w tym nowym świecie profesjonalnego prawa, profesjonalnego sprawowania władzy oraz ujednoznacznionych przywilejów ustaliło się szlachectwo wasali - przynajmniej w kodeksach prawnych. Właśnie akademickie prawo o lennach było pierwszym, które głosiło, że lenna są własnością szlachecką"18.

Zdaniem S. Reynolds dwustronne relacje interpersonalne, zwłaszcza różnorodne stosunki zależności osobistej, nie były głównym spoiwem

16 ,the point seems to have been to secure a measure of political subordination from the new fiefholder, often symbolized by oaths and some kind of ceremony of homage. [- - ] Conceptualizations of anything like the «feudal pyramid» or a «hierarchy of tenure» as they are understood today, so far as they are discernible at all, begin to appear in this period", ibidem, s. 68, 70 .

17 „were presumably set on the way to nobility, however loosely understood", ibidem, s. 44 .

18 „It is surely no accident that it was in this new world of professional law, professional government, and defined privileges that the nobility of vassals became established - at least in the lawbooks. It was the academic law of fiefs that first declared that fiefs were noble property", ibidem. 
społeczeństw zachodniej Europy wcześniejszego średniowiecza. Spójność społeczna była natomiast funkcją konsensualnego systemu rządzenia, zbiorowego wymiaru sprawiedliwości, funkcjonowania prawa i zwyczaju, przywiązania do idei dobra wspólnego, przekonania o prawomocności hierarchii i o potrzebie lojalności, braku ostrych podziałów klasowych ${ }^{19}$. Jest to zupełnie inny punkt widzenia niż M. Blocha,że społeczeństwo feudalne cechowały stosunki zależności osobistej, przede wszystkim „zależność podwładnego od bliskiego zwierzchnika"20.

Tak radykalna reinterpretacja dotychczasowych poglądów na feudalizm wasalno-lenny musiała wywołać dyskusję wokół kwestii ogólnych i szczegółowych. Nie mamy tutaj możliwości jej referowania. Natomiast poświęcimy nieco uwagi najważniejszej kwestii ogólnej, także w kontekście badań feudalizmu w Europie Środkowo-Wschodniej. Chodzi o defeudalizację średniowiecznej Europy Zachodniej.

Krytycy książki S. Reynolds powiadają, że w dekonstrukcji feudalizmu posuwa się ona zbyt daleko. Na przykład Dominique Barthélemy, który mimo swojego przywiązania do modelu feudalnego Zachodu przyjmuje argumenty Reynolds dotyczące konieczności odrzucenia nowożytnych schematów na temat feudalizmu, stwierdza: ,jej krytyka historiograficzna obraca się niefortunnie w destrukcję prawdziwych zjawisk historycznych"21.

Z kolei Stephen D. White, nawiązując do podzielanego przez niektórych badaczy poglądu, inspirowanego socjologią Marcela Maussa, że wzorcem dla relacji wasalno-lennej była wymiana darów, podjął się nawet empirycznej weryfikacji dokonań S. Reynolds w zakresie demontażu koncepcji feudalizmu, odwołując się mianowicie do tekstów literackich z pełnego średniowiecza mówiących o darze jako medium nawiązywania relacji interpersonalnych. Autor konkluduje w związku z tym: „Chociaż pouczające jest dekonstruowanie i demistyfikowanie «feudalizmu» - jak z talentem dokonała tego Reynolds - poprzez sprowadzanie praktyk niegdyś kojarzonych z władztwem, wiernością i wymianą darów do ciągu heterogenicznych działań politycznych w konkurencyjnej grze arystokracji o władzę

${ }^{19}$ Zob. też S. Reynolds, Afterthoughts on „Fief and Vassals”, „The Haskins Society Journal" 9, 1997, s. 1-16 (ostatnio dostępne w: eadem, The Middle Ages without Feudalism. Essays in Criticism and Comparison on the Medieval West, Farnham 2012, nr I); eadem, Fiefs and Vassals after Twelve Years, w: Feudalism. New Landscapes of Debate, wyd. S. Bagge, M.H. Gelting, T. Lindkvist, Turnhout 2011, s. 15-26.

${ }^{20}$ M. Bloch, Społeczeństwo feudalne, Warszawa 2002 (oryg. franc. 1973), s. 431.

${ }^{21}$ „sa critique historiographique tourne malencontreusement à la destruction de vrais objets historiques", D. Barthélemy, La théorie féodale à l'épreuve de l'anthropologie (note critique), „Annales. Histoire, Sciences Sociales” 52, 1997, 2, s. 321-341, cytat s. 340. 
polityczną, to jest istotne, aby pamiętać, że gra jako taka była ustalona kulturowo i że samo to ustalenie było procesem politycznym, który nie był całkowicie kierowany przez jakieś państwo lub władzę"22.

Należy podkreślić, że S. D. White, koncentrując się na cyrkulacji darów, zbyt wąsko traktuje zagadnienie wymiany. Już bez mała cztery dekady temu w badaniach zagadnienia klienteli, a zatem problematyki pokrewnej $\mathrm{z}$ feudalizmem wasalno-lennym, odwoływano się do szerzej rozumianych socjologicznych teorii wymiany. Inna sprawa, że wówczas skupiano uwagę na relacji dwustronnej (diadzie) patron - klient, co trzeba uznać za poważne ograniczenie problematyki wymiany społecznej ${ }^{23}$.

Współczesna teoria wymiany społecznej może być, jak się wydaje, atrakcyjnym narzędziem w badaniach feudalizmu. Stanowi ona rozwinięcie idei wysuniętej jeszcze przez Georga Simmela, że wymiana jest „głównym czynnikiem twórczym społeczeństwa" ${ }^{24}$. Orientacja antropologiczna tej teorii koncentruje się na społecznym (strukturalnym) kontekście wymiany rozumianej jako sfera komunikacji społecznej: „wymiana traktowana być może jako symboliczna interakcja bądź poprzez uwzględnienie towarzyszących transakcjom zabiegów definicyjno-interpretacyjnych dokonywanych przez zaangażowane w wymianę jednostki, bądź poprzez umiejscowienie jej aktów w całościowo ujmowanej matrycy znaczeń, osadzonej w szerszym, kulturowym, nie zaś czysto sytuacyjnym kontekście" ${ }^{25}$.W orientacji behawioralnej kładzie się nacisk na niezależne od kontekstu społecznego motywacje skłaniające jednostki do

${ }^{22}$ „Although it is instructive to deconstruct and demystify «feudalism» - as Reynolds has ably done - by reducing the practices once associated with lordship, fidelity, and gift-exchange to a series of heterogenous political manoeuvers in a competitive game of aristocratic power politics, it is important to remember that the game itself was culturally constructed and that its construction was itself a political process that was not strictly regulated by any state or government", S. D. White, The Politics of Exchange: Gifts, Fiefs and Feudalism, w: Medieval Transformations: Texts, Power, and Gifts in Context, red. E. Cohen, M.B. de Jong, Leiden 2001, s. 169-188, cytat s. 185 n.; por. idem, Giving Fiefs and Honor: Largesse, Avarice, and the Problem of „Feudalism” in Alexander's Testament, w: The Medieval French Alexander, red. D. Maddox, S. Sturm-Maddox, Albany-New York 2002, s. 127-141; idem, Service for Fiefs or Fiefs for Service. The Politics of Reciprocity, w: Negotiating the Gift: Pre-Modern Figurations of Exchange, red. G. Algazi, V. Groebner, B. Jussen, Göttingen 2003, s. 63-98.

${ }^{23}$ Zob. przeglądowy artykuł H.-H. Nolte, Patronage und Klientel: Das Konzept in der Forschung, w: Patronage und Klientel. Ergebnisse einer polnisch-deutschen Konferenz, red. idem, Köln-Wien 1989, s. 1-17.

${ }^{24}$ G. Simmel, Wdzięczność. Próba ujęcia socjologicznego (1907), w: idem, Pisma socjologiczne, Warszawa 2008 (oryg. niem. 1983), s. 216.

${ }^{25}$ M. Kempny, Wymiana społeczna - teoria socjologiczna. W stronę kulturowej perspektywy czy poza nią?, w: Struktura - wymiana - władza. Studia z socjologii teoretycznej, red. T. Sozański i in., Warszawa 1993, s. 288. 
wchodzenia w relacje wymiany. Konsekwencją procesów wymiany są zjawiska strukturalne (normy, instytucje itp.). Przyjmuje się założenie „postulujące istnienie jakichś naturalnych, wspólnym jednostkom jako takim, niezależnych od kontekstu społecznego sposobów zachowań, które tkwią u podstaw wszelkich bardziej złożonych zjawisk społecznych (normy, instytucje, struktury etc.)"26. Wreszcie w orientacji strukturalnej zwraca się uwagę na koncepcję „struktury jako «wielowymiarowej przestrzeni pozycji społecznych, pośród których rozmieszczeni są członkowie populacji», oraz rozróżnienie między «strukturą relacji» $\mathrm{i}$ «strukturą pozycji społecznych»”. Zróżnicowanie strukturalne jest „siłą zewnętrzną, ograniczającą decyzje i działania jednostek" ${ }^{27}$. W tzw. teorii elementarnej Davida Willera, mieszczącej się w tej ostatniej orientacji, w centrum stawia się zagadnienie struktur i mechanizmów rodzących zjawiska wymiany, przymusu, dominacji, konfliktu, eksploatacji, kompromisu ${ }^{28}$. Szczególnie interesująca wydaje się sieciowa teoria wymiany, będąca wariantem teorii elementarnej, w której wymiana rozumiana jako zdarzenie/transakcja/stosunek społeczny „traktowana jest zawsze jako składnik jakiejś «całości społecznej» lub przejaw jej dynamiki”29.

Nowoczesne badania wymiany społecznej w Europie średniowiecznej czekają na podjęcie. Mogą one otworzyć nowe perspektywy w badaniach nad feudalizmem. Wbrew postulatowi S. Reynolds nie ma bowiem ani potrzeby, ani powodu, aby rezygnować z pojęcia feudalizmu. Natomiast warto pójść za cytowaną autorką w pewnej relatywizacji znaczenia feudalizmu jako spoiwa średniowiecznych społeczeństw Zachodu, a także w datowaniu pojawienia się feudalizmu na początek pełnego średniowiecza.

Jeszcze w latach trzydziestych ubiegłego stulecia Norbert Elias wyraził pogląd, że „Tak zwany «system feudalny», który w XII stuleciu występuje wyraźniej, a w XIII jest już w dużej mierze ugruntowany, nie jest niczym innym, jak formą zamykającą [- - ] proces ekspansji w sektorze agrarnym społeczeństwa" ${ }^{30}$. Autorowi chodziło o to, że proces ekspansji, która rozpoczęła się w XI w., natrafił na przeszkodę w postaci wyczerpującego się

${ }^{26}$ Ibidem, s. $275 \mathrm{nn}$.

${ }^{27}$ P. M. Blau, Wymiana i władza w życiu społecznym, Kraków 2009 (oryg. ang. 1986), s. VIII, XI n.

${ }^{28} \mathrm{~J}$. Szmatka, D. Willer, W kierunku teoretycznego programu badawczego dynamiki struktury społecznej, w: Struktura - wymiana - władza, s. 44; I. Uhl, Co to jest ,teoria elementarna"?, w: Struktura - wymiana - władza, s. 74; W. Strykowski-Kozień, Dynamika struktury społecznej, w: Struktura - wymiana - władza, s. 130.

${ }^{29}$ T. Sozański, Próba formalizacji sieciowej teorii wymiany, w: Struktura - wymiana władza, s. 152.

${ }^{30}$ N. Elias, Socjogeneza feudalizmu, w: idem, Przemiany obyczajów w cywilizacji Zachodu, Warszawa 1980 (oryg. niem. 1969), s. 319. 
zasobu ziemi: „Stan posiadania ulega petryfikacji. [- - ] I równolegle też petryfikują się różnice stanowe między wojownikami"31. Problem wydaje się bardziej skomplikowany.

W związku z tym warto zwrócić uwagę na zjawisko, które Fred Hirsch określa mianem „rzadkości społecznej” („social scarcity”). Chodzi o to, że otoczenie społeczne może powstrzymywać upowszechnianie użycia danego dobra, usługi etc.,jeżeli jakość tego użycia miałaby ulec pogorszeniu. Albowiem zadowolenie $\mathrm{z}$ używania dobra/usługi wynika $\mathrm{z}$ warunków towarzyszących temu użyciu, a nie z użycia jako takiego ${ }^{32}$. Bezwzględna podaż danego dobra może być zatem ograniczana nie tyle przez czynniki fizyczne, ile przez czynniki społeczne, motywowane zazdrością, dumą czy rywalizacją. Zadowolenie jest czerpane z pozycji pierwszeństwa w stosunku do innych: „Rozporządzanie specyficznymi dobrami i usługami w określonym czasie i w określonych warunkach, kiedy one ujawniają się jako symbole statusu, staje się wskaźnikiem takiego pierwszeństwa. Kiedy wyłącznym lub głównym źródłem zadowolenia staje się raczej symbol niż majątek, można to traktować jako czystą rzadkość społeczną"33.

Dobra, usługi, stanowiska, relacje społeczne etc., które są rzadkie fizycznie lub społecznie, wchodzą w zakres gospodarki pozycjonalnej (positional economy). W okresie wzrostu gospodarczego rośnie popyt na dobra pozycjonalne oraz ich cena w stosunku do dóbr materialnych. Z kolei popyt na dobra pozycjonalne powiększa popyt na dobra materialne.Powyżej pewnego progu konsumpcji dóbr materialnych niezbędne jest pozyskanie dodatkowych dóbr pozycjonalnych (np. usług) dla obsługi powiększonego zasobu dóbr materialnych ${ }^{34}$.

Jeżeli rzadkość społeczna wynika z rzadkości fizycznej, regulatorem dostępu do dobra pozycjonalnego jest mechanizm cenowy. Jeżeli natomiast rzadkość społeczna wynika z dążenia do utrzymania odpowiedniej jakości używania dobra, dostęp do dobra pozycjonalnego jest reglamentowany poprzez różnego rodzaju ograniczenia, wykluczenia etc. ${ }^{35}$

Ziemia od XI w. nabierała właściwości dobra pozycjonalnego. Z jednej strony w rodach arystokratycznych młodsi synowie byli odsuwani od

${ }^{31}$ Ibidem, s. 320.

${ }^{32}$ F. Hirsch, Social Limits to Growth, London-Henley 1977, s. 3.

33 "Command over particular goods and facilities in particular times and conditions becomes indicator of such precedence in its emergence as a status symbol. Where the sole or main source of satisfaction derives from the symbol rather than the substance, this can be regarded as pure social scarcity", ibidem, s. 20-21.

${ }^{34}$ Ibidem, s. 28. Por. P. Bourdieu, Dystynkcja: społeczna krytyka władzy sadzenia, Warszawa 2005 (oryg. franc. 1979), s. 302-318 - o „walkach symbolicznych”.

${ }^{35}$ F. Hirsch, op. cit., s. 28-30. 
dziedziczenia majątków ziemskich ${ }^{36}$. Można w tym widzieć przykład wymiany społecznej z zasadą wykluczenia ${ }^{37}$. Z drugiej strony najstarsi synowie stawali się lennikami możnych panów; dzierżyli odziedziczony fundusz ziemi (z reguły powiększony przez nowego seniora) jako feudum oblatum (a nie jako własność pełną), częścią tego funduszu uposażali własnych lenników. Wszystko to można uważać za przykłady wymiany społecznej z zasadą włączenia ${ }^{38}$. W tle tych zjawisk wymiany społecznej był ogólny wzrost materialny Zachodu w pełnym średniowieczu, napędzany przez ekspansję demograficzną. Nie jest przypadkiem, że feudalizm pojawił się najwcześniej w najbardziej dynamicznych gospodarczo i społecznie krajach. Fizyczna rzadkość ziemi miała co najwyżej relatywne znaczenie $\mathrm{w}$ jej przekształcaniu się w dobro pozycjonalne; ważniejsza była jej rzadkość społeczna. Posiadanie ziemi jako lenna było równoznaczne z jej posiadaniem na najlepszych z możliwych warunkach. Pozycja lenników jako dysponentów „dobra symbolicznego” była umacniana przez właściwy im kapitał kulturowy (kulturę feudalną). Ponieważ rywalizacja o feudalne pozycje społeczne była wymianą (grą) o sumie zerowej, część przedstawicieli świata arystokratycznego była zmuszona do migracji na peryferie świata chrześcijaństwa zachodniego. Do problematyki tej „diaspory arystokratycznej” ${ }^{39}$ przyjdzie powrócić w dalszej części tego artykułu.

Powstaje z kolei pytanie, jak zaproponowana przez S. Reynolds destrukcja modelu feudalnego Zachodu została przyjęta w mediewistyce dotyczącej krajów, o których ustaliła się w historiografii opinia, że nie znały feudalizmu wasalno-lennego lub zetknęły się z nim marginalnie. Przykładowo, Michael H. Gelting w związku z historią średniowiecznej Danii powiada: „Obecnie zarysowuje się niejaka konwergencja między zburzeniem zbyt rygorystycznego modelu «klasycznego» feudalizmu promieniującego z północnej Francji a odkryciem pewnej autochtonicznej «feudalizacji» w krajach rzekomo peryferyjnych" ${ }^{40}$. Warunkiem

${ }^{36}$ Dyskusję na ten temat referuje R. Bartlett, op. cit., rozdz. 2: „Diaspora arystokratyczna".

${ }^{37}$ W sprawie modeli sieci wymian z zasadą wykluczenia, zob. J. Szmatka, D. Willer, op. cit., s. 54 nn.

${ }^{38}$ W sprawie modeli sieci wymian z zasadą włączenia - ibidem, s. $59 \mathrm{nn}$.

${ }^{39}$ R. Bartlett, op. cit., rozdz. 2.

40 „il se dessine à présent une certaine convergence entre le démantèlement d'un modèle trop rigide d'une féodalité «classique» rayonnant depuis la France septentrionale et le dévoilement d'une «féodalisation» autochtone dans les pays de la préten- 
odkrycia owej ,autochtonicznej feudalizacji” jest - zdaniem autora zwrócenie uwagi nie tyle na zróżnicowanie instytucjonalne, ile na mechanizmy praktycznego wykonywania władzy. Wtedy okazuje się, że w zakresie doświadczania relacji klienteli, sąsiedztwa, przyjaźni, pokrewieństwa itp. stwierdza się w Danii ewolucję paralelną do tej obserwowanej w Europie Zachodniej, uważanej za feudalną. Konkluzja autora jest następująca: „Przeto model jakiejś bardzo zapóźnionej ewolucji skandynawskiej nie ma już racji istnienia" ${ }^{41}$.

Dodajmy, że w innej publikacji M.H. Gelting pisze o specyficznym duńskim feudalizmie będącym konsekwencją podjęcia w XII w. decyzji politycznej o odrzucenia lenna. Oto obecność lub nieobecność w Danii lenna jest - jego zdaniem - co najwyżej odzwierciedleniem powierzchownych różnic w stosunku do feudalnego Zachodu. Istota sprawy leżała głębiej, mianowicie w adaptacji przez duńskich magnatów europejskiej kultury rycerskiej oraz władztwa gruntowego, a także w układach społecznych opartych na relacjach krewniaczych, przyjacielskich i relacjach wierności ${ }^{42}$.

Zwróćmy z kolei uwagę na wypowiedź Antona A. Gorskiego (Anton Anatol'evič Gorskij) dotyczącą feudalizmu na Rusi.Jego zdaniem nie da się określić społeczeństwa ruskiego mianem feudalnego w znaczeniu wasalno-lennym, jednak - z drugiej strony - ,ten «klasyczny model» w rzeczywistości praktycznie nigdzie nie istnial" ${ }^{3}$. Natomiast powszechnym zjawiskiem w Europie było panowanie warstwy wojenno-służebnej nad pospolitą ludnością, i tak było także na Rusi. Można to społeczeństwo - powiada nasz autor - nazwać feudalnym, można poszukać innego terminu: „Lecz najważniejsze jest, aby nie zasklepiać się w sporach terminologicznych, lecz dyskutować o realiach ustroju społecznego. Współczesny stan ich rozpoznania pozwala [- - ] mówić o zasadniczej typologicznej jedności rozwoju społecznego krajów Europy w epoce średniowiecza" ${ }^{44}$.

due périphérie”, M. H. Gelting, Féodalisation sans féodalité dans le Danemark médiéval: une question mal posée?, w: Die Gegenwart des Feudalismus, s. 137-151, tutaj s. 137; por. utrzymany w podobnym duchu artykuł Erika Opsahla dotyczący „europeizacji” Norwegii: idem, , [...] nonetheless [he] fulfilled his obligations towards the hirð”: Fealty and Politics in Medieval Norway, w: Feudalism. New Landscapes of Debate, s. 185-201.

${ }^{41}$ „Par conséquent, le modèle d'une évolution scandinave fortement retardataire n'a plus de raison d'être", ibidem, s. 148-149.

${ }^{42}$ M.H. Gelting, The Problem of Danish „Feudalism”. Military, Legal, and Social Change in the Twelfth and Thirteenth Centuries, w: Feudalism. New Landscapes of Debate, s. 159-184.

${ }^{43}$ A. A. Gorskij, O „feodalizme”: ,russkom" i ne tol'ko, „Srednie veka” 69, 2008, 4, s. 9-26, tutaj s. 26.

44 „No glavnoe - ne zamykat'sâ na terminologičeskih sporah, a rassuždat' o realiâh social'nogo stroâ. Sovremennoe sostoânie ih izučeniâ pozvolâet [- - ] govorit' o principial'nom tipologičeskom edinstve obŝestvennogo razvitiâ stran Evropy 
Na przykładzie historiografii dotyczącej Danii oraz Rusi można stwierdzić, że badacze zajmujący się peryferiami feudalizmu przyjęli tezy S. Reynolds dużo życzliwiej niż historycy badający „feudalizm klasyczny". W konsekwencji dokonana przez S. Reynolds destrukcja pojęcia feudalizmu w czołowych krajach średniowiecznego Zachodu zachęciła niektórych mediewistów do tego, aby zacierać różnicę między częścią Europy uważanej (do niedawna) za feudalną a krajami peryferyjnymi, w tym położonymi w środkowo-wschodniej części kontynentu. $\mathrm{W}$ tym kontekście zwraca uwagę, że we współczesnej mediewistyce polskiej zachodnioeuropejskie spory o feudalizm znalazły słaby odzew ${ }^{45}$. Widzieć w tym należy skutek oddziaływania mediewistyki niemieckiej, która z rezerwą odnosi się do pojęcia feudalizmu, ograniczając się do wąsko rozumianego lennictwa (Lehnswesen), i która ignoruje bądź odrzuca hipotezy S. Reynolds ${ }^{46}$.

v èpohu Srednevekov'â", ibidem, s. 26. We współczesnej historiografii rosyjskiej poświęca się sporo uwagi problematyce feudalizmu (tj. rewolucji/mutacji feudalnej okoto roku 1000 oraz defeudalizacji à la S. Reynolds); zob. tytułem przykładu reprezentatywną publikację: Feodalizm: ponâtie i realii, red. A. Â. Gurevič, S. I. Lučickaâ,P.Û. Uvarov, Moskva 2008; por. także I. V. Dubrovskij, P. U. Uvarov, Feodalizm v predstavlenii sovremennyh medievistov, w: Vsemirnaâ istoriâ, t. 2: Srednevekovye civilizacii Zapada i Vostoka, red. P. U. Uvarov, Moskva 2012, s. 16-32.

${ }^{45}$ Odnotować trzeba artykuł Grzegorza Myśliwskiego, Feudalizm - „rewolucja feudalna" - kryzysy władzy w Polsce XI-początku XII w. Punkt widzenia mediewistyki anglojęzycznej, PH 93, 2002, 1, s. 73-102.

${ }^{46}$ „Obwohl also allgemein als Grundbegriff etabliert, wurde der Feudalismus in jüngster Zeit in Deutschland nur wenig als fortbestehende Forschungs- und Diskussionsaufgabe ernstgenommen”, L. Kuchenbuch, „Feudalismus”: Versuch über die Gebrauchsstrategien eines wissenspolitischen Reizwortes, w: Die Gegenwart des Feudalismus, s. 299. W sprawie stosunku Niemców do poglądów S. Reynolds zob. ostatnio: J. Dendorfer, Zur Einleitung, w: Das Lehnswesen im Hochmittelalter. Forschungskonstrukte - Quellenbefunde - Deutungsrelevanz, red. idem, R. Deutinger, Ostfildern 2010, s. 14-23; zauważa się tutaj pewną otwartość na nowe myślenie o feudalizmie, por. np. s. 21: „Der folgende Band soll hier ansetzen, indem er die methodischen Anregungen Reynold's aufgreift und nach der Ausformung der Konzepte «Lehen» und «Vassalität» fragt"; por. też s. 22 z wypowiedzią w podobnym duchu. Natomiast Werner Hechberger (Das Lehnswesen als Deutungselement der Verfassungsgeschichte von der Aufklärung bis zur Gegenwart, w: Das Lehnswesen im Hochmittelalter, s. 53-55) deklaruje przywiązanie do dawnych schematów, chociaż dodaje: „Die Fundamentalkritik von Susan Reynolds mag also überzogen und aus wissenschaftstheoretischen Gründen in Teilen anfechtbar sein. Sie hat aber eine Debatte angestoßen, die durchaus neue Erkenntnisse zu liefern verspricht" (s. 55). Zawartość dopiero co opublikowanego tomu Ausbildung und Verbreitung des Lehnswesens świadczy o upowszechnianiu się w historiografii niemieckiej poglądu, że „Das Ineinander von Lehen und Vasallität wird [- - ] immer deutlicher als ein Kind des 11. Jahrhunderts erkennbar" (S. Patzold, Das Lehnswesen im Spiegel historiographischer Quellen des 12. und 13. Jahrhunderts, w: Ausbildung und Verbreitung des Lehnswesens, s. 268-306, tutaj s. 270). 
Podejmując kwestię feudalizmu w Europie Środkowo-Wschodniej, nie pójdziemy śladem M.H. Geltinga, tzn. nie będziemy zajmowali się „feudalizacją bez feudalizmu". Interesuje nas zagadnienie feudalizmu lennego lub zbliżonego do lennego. Ostatnie dwie dekady przyniosły niemało publikacji na ten temat; najważniejsze z nich warto razem zestawić i krytycznie omówić.

Zanim przejdziemy do naszej problematyki, należy wyjaśnić zakres geograficzny i chronologiczny niniejszego przyczynku. Jak wiadomo, w historiografii nie ma zgodności w kwestii definiowania Europy Środkowo-Wschodniej ${ }^{47}$.Zatem nie wdając się w rozważania na ten temat, umieściliśmy w centrum naszego zainteresowania królestwa Polski, Czech i Węgier. Zagadnieniu feudalizmu w średniowiecznych Prusach poświęciliśmy przyczynek przed 15 laty $^{48}$, natomiast feudalizmem w Inflantach tej epoki zamierzamy zająć się w przyszłości. Ramy czasowe naszych uwag wyznaczone są w zasadzie przełomem XII/XIII w. oraz wiekiem XV.

\section{IV}

Opublikowane w nieodległej przeszłości prace przeglądowe na temat badań feudalizmu w Polsce średniowiecznej zwalniają nas od podejmowania podobnego zadania ${ }^{49}$. Ostatnim słowem w krajowej historiografii na interesujący nas temat są prace Sławomira Gawlasa, zawierające próbę odpowiedzi na pytanie, dlaczego w Polsce nie było feudalizmu lennego ${ }^{50}$. Zdaniem autora w XII w. ta część polskiego rycerstwa, która była podporządkowana możnym dążącym do zbudowania swoich władztw terytorialnych, upodabniała się do niemieckich ministeriałów. Nie dotyczyło to rycerzy podległych książętom: „Opóźnienie rozwoju społecznego prowadziło do tego, że pomimo rycerskiej obyczajowości na dworze, w stosunkach z poddanymi znalazły zastosowanie «archaiczne», służebne formy zależności” ${ }^{51}$. Nie jest jasne, o jakie „archaiczne” formy zależności tutaj

47 Por. z nowszej literatury np. East-Central Europe's Position within Europe. Between East and West, red. J. Kłoczowski, Lublin 2004; Europa Środkowowschodnia od X do XVIII wieku - jedność czy różnorodność?, red. K. Baczkowski, J. Smolucha, Kraków 2005.

${ }^{48}$ M.Dygo, Feudalizm w Prusach w XIII-XVI wieku, RDSG 58, 1998, s. 143-153.

${ }^{49}$ Zob. S. Kwiatkowski, Polska mediewistyka historyczna w czasach maszynopisu. 0 wymuszonej modernizacji i okolicznościach jej przemijania (wybrane zagadnienia), Poznań 2010, s. 42-50; tutaj odniesienia do dalszej literatury przeglądowej.

${ }^{50}$ S. Gawlas, Dlaczego w Polsce nie było feudalizmu lennego?, RDSG 58, 1998, s. 101-123; idem, Die Probleme des Lehnswesens und des Feudalismus aus polnischer Sicht, w: Das europäische Mittelalter im Spannungsbogen des Vergleichs, s. 97-123. Korzystamy z niemieckojęzycznej, obszerniejszej wersji artykułu.

51 „Die Verspätung der gesellschaftlichen Entwicklung führte dazu, dass trotz der 
chodzi. Zdaniem S. Gawlasa, rozprzestrzenianie się (z Niemiec) prawa lennego oraz lenne ujednolicenie statusu rycerzy-,,ministeriałów” doprowadziłoby do tego, że i w Polsce prawo lenne „stałoby się składnikiem struktury społecznej oraz narzędziem władztwa terytorialnego"52. Jeśli do tego nie doszło, to dlatego, że Piastowie, świadomi zagrożeń dla władzy książęcej płynących ze strony możnych, posłużyli się recypowanymi z Niemiec bezpośrednio lub pośrednio zasadami organizacji władzy terytorialnej, takimi jak regalia, ius ducale oraz monopol na pożytki z kolonizacji na prawie niemieckim. Konkluzja autora jest następująca: „Konsekwentnie prowadzona polityka książąt jest moim zdaniem główną przyczyną upośledzenia elit możnowładczych w XIII w. [-- ] W sumie udało się książętom piastowskim [- - ] utrzymać rycerstwo w bezpośredniej zależności oraz powstrzymać rozwój względnie przekształcanie możnowładczej klienteli w lennych wasali. Przeto brakowało warunków do oddolnej recepcji prawa lennego. To miało poważne konsekwencje społeczne. Zależność lenna, pierwotnie powołana do życia jako przeciwieństwo związków pokrewieństwa, w XIII w. nadal ograniczała prawa krewnych bocznych. Jest zatem zrozumiałe, że [- - ] więzy rodzinne i rodowe pozostały podstawową formą związków społecznych, względnie takimi na nowo się stały"53.

Poglądy S. Gawlasa spotkały się w literaturze przedmiotu z różnym przyjęciem. Tomasz Jurek wydaje się całkowicie akceptować tok rozumowania autora i wyprowadzone wnioski, dodając: „Chciałoby się więc raczej pytać nie o to, dlaczego stosunki lenne się nie przyjęły, lecz o to, dlaczego w ogóle się pojawiły" ${ }^{\text {4 }}$. Natomiast Wojciech Piasek, komentu-

ritterlichen Sitten am Hofe in den Beziehungen zu den Untergebenen «archaische», dienstbarere Formen der Abhängigkeit Verwendung fanden", S. Gawlas, Die Probleme des Lehnswesens, s. 116/117.

52 „In Anbetracht all dessen wäre zu erwarten, dass die weitere Entwicklung des Lehnrechts dessen stärkere Diffusion hätte nach sich ziehen müssen, so daß es zum gesellschaftlichen Strukturelement und Instrument der Territorialherrschaft geworden wäre", ibidem, s. 117.

53 „Die so konsequent geführte fürstliche Politik ist meines Erachtens die Hauptursache für die Zurücksetzung der hochadeligen Eliten im 13. Jahrhundert. [- - ] Insgesamt gelang es den Piastenfürsten [--], die Ritterschaft in unmittelbarer Abhängigkeit zu halten und den Aufstieg bzw. die Umgestaltung der hochadeligen Klientel in Lehnsvasallen zu verhindern. Es fehlten somit Bedingungen zur Rezeption des Lehnrechts von unten. Dies hatte gravierende gesellschaftliche Folgen. Die Lehnsabhängigkeit, usrprünglich als Antipode gegen verwandtschaftliche Bindungen geschaffen, begrenzte im 13. Jahrhundert weiterhin die Rechte der Seitenverwandten. Von daher ist verständlich, dass [- - ] die Familien- und Geschlechterbande die Grundform sozialer Bindungen blieben bzw. sich als solche neu konstituieren", ibidem, s. 117-118.

${ }^{54}$ T. Jurek, Omagialitas alias manowstwo. Przyczynek do dziejów recepcji prawa lennego 
jąc książkę S. Gawlasa o „zjednoczonym Królestwie”, która była jedną z podstaw napisania omawianego artykułu, stwierdził: , jej oś, na poziomie wizji świata i człowieka, stanowi śledzenie rozwiązań instytucjonalnych i ogólnie zjawisk społeczno-ustrojowych w kontekście obiektywizacji i racjonalizacji «zarządzania państwem i jego terytorium»". W. Piasek preferuje podejście właściwe antropologii kulturowej, która „ma zrozumienie inności kultury badanej, nie imputowanie jej sensów społecznych i ekonomicznych z kultury badacza, ale rekonstruowanie swoistego dla niej kontekstu myślowego, którego rozpoznanie pozwala na niemodernizujące jej ujęcie" 55 . Ze swej strony ujęcie modernizujące problematykę feudalizmu bez wahania przypiszemy oddziaływaniu historiografii niemieckiej ${ }^{56}$.

W każdym razie przywołane przez S. Gawlasa informacje z kroniki Anonima Galla (II 4) o komesie Sieciechu, który ludzi niskiego pochodzenia wynosił ponad szlachetnie urodzonych, nie mogą być podstawą szeroko zakrojonych wniosków w zakresie recepcji ministerialitetu w Polsce przełomu XI/XII w. ${ }^{57}$ Bardziej trafia nam do przekonania interpretacja zaproponowana przez K. Modzelewskiego, który ukazał na podstawie

w średniowiecznej Wielkopolsce, w: Kościót - kultura - społeczeństwo. Studia z dziejów średniowiecza i czasów nowożytnych, red. S. Bylina i in., Warszawa 2000, s. 259-271, cytat s. 271.

${ }^{55}$ W. Piasek, Wokót koncepcji feudalizmu. W dialogu kulturowym ze współczesna mediewistyka polska, w: Mediewistyka polska w XX wieku (wybrane problemy), red. S. Kwiatkowski, Wrocław 2008, s. 65-75, cytaty s. 69, 72; por. S. Kwiatkowski, op. cit., s. 47 n. Zob. S. Gawlas, o kształt zjednoczonego Królestwa. Niemieckie władztwo terytorialne a geneza społeczno-ustrojowej odrębności Polski, Warszawa 1996, rozdz. 12.

${ }^{56}$ Por. J. Dendorfer, op. cit., s. 20-21: „,in Deutschland stehen Ganshof und Mitteis immer noch für konzeptionelle Fassung der Diskussion. [- - Im deutschsprachigen Raum gilt es, das Potenzial des erweiterten Fragehorizonts, den der breitere Feudalismusbegriff bietet, zumindest als Anregung aufzugreifen, um den Stellenwert des Lehnswesens im Rahmen der Ordnungskonfigurationen des Früh- und Hochmittelalters neu zu bestimmen".

${ }^{57}$ Notabene G. Myśliwski poszedł jeszcze dalej, pisząc w związku z działaniami Sieciecha: „Bardzo prawdopodobne wydają się [- - ] analogie między «rewolucją feudalną» a przemianami społeczno-politycznymi w Polsce ostatniej ćwierci XI i pierwszych kilkunastu lat XII w. [- - ] Świadczy o tym Sieciechowa taktyka i budowy sieci grodów,i promowania ludzi spoza elity, «niższego stanu» [- - ] na urzędy terytorialne (grody kasztelańskie)", G. Myśliwski, op. cit., s.102.W świetle książki S. Reynolds pojęcie rewolucji / mutacji feudalnej około roku 1000 budzi o tyle wątpliwości, że lenno w owej transformacji porządku postkarolińskiego odgrywało drugorzędną rolę; G. Duby wykazał to jeszcze w połowie ubiegłego wieku. Dlatego nie sposób zgodzić się z opinią Jürgena Dendorfera (op. cit.,s. 19): „Vor dem Hintergrund der Diskussion um die «mutation féodale» läuft die Kritik von Reynolds an den «feudo-vassalitischen Institutionen» zumindest zu einem Teil ins Leere". Inna sprawa, że z pojęcia „rewolucji feudalnej” nie warto rezygnować, tyle że należałoby datować ją na przełom XI i XII w.; por.ostatnio Ch. West, Reframing the Feudal Revolution.Political and Social Transformation Between Marne and Moselle, c. 800-c.1100, Cambridge 2013, s. $259 \mathrm{nn}$. 
kroniki Galla oligarchię złożoną z urzędniczego możnowładztwa, spojoną solidarnością rodową oraz przekonaniem o powołaniu do piastowania wysokich godności opartym na przymiotach charyzmatycznych. Owa elita była wrogo nastawiona do powierzania wysokich urzędów ludziom pospolitej kondycji ${ }^{58}$.

Pogląd o jakiejś recepcji ministerialitetu w środowisku klienteli polskiego możnowładztwa we wcześniejszym i pełnym średniowieczu pojawił się w naszej historiografii mniej więcej przed stuleciem i zadomowił się w niej na stałe ${ }^{59}$. Powstaje jednak pytanie, w jakim znaczeniu używa się tutaj terminu ministerialitet. Wydaje się, że dominuje pogląd wyrażony przed wojną przez Mariana Friedberga: „Porównać należy [--] nie tyle formy prawne, ile samą istotę zjawiska społecznego. Jest nią grupa społeczna, pełniąca funkcje wojskowe, dworskie i gospodarcze (włodarze) na rzecz swoich panów. Tworzą ją zasadniczo ludzie niskiego pochodzenia, choć sporadycznie mogą się trafiać i wolni rycerze" ${ }^{60}$. Postulat ten jest w istocie tożsamy z przytoczonym wyżej poglądem M.H. Geltinga,że instytucje są drugorzędne i wystarczy zająć się „feudalizacją bez feudalizmu”. Nie podzielamy tego punktu widzenia, ponieważ następstwem jego przyjęcia musi być zacieranie różnic między regionami czy krajami, jeśli chodzi o występowanie feudalizmu lennego. Materiał zestawiony przez M. Friedberga nie daje podstaw do twierdzenia, że w Polsce pełnego średniowiecza miała miejsce adaptacja instytucji ministerialitetu. Cytowany uczony zauważył co prawda, że polskie „rycerstwo służebne [- - ] daje się poznać dokładniej dopiero od początku w. XIII, kiedy to występuje od razu nie w pierwotnym, ale już nieco późniejszym stadium rozwoju społecznego"61. Niedawno Jerzy Strzelczyk wyraził pogląd, że polscy ministeriałowie, jakkolwiek liczni, nie byli oznaczani osobną nazwą i dlatego są słabo uchwytni w źródłach ${ }^{62}$.Jednak w najnowszych badaniach dotyczących relacji między prawem lennym i prawem ministeriałów (tj. prawem dworskim) zwraca

${ }^{58}$ K. Modzelewski, Comites, principes, nobiles. Struktura klasy panujacej w świetle terminologii Anonima Galla, w: Cultus et cognitio. Studia z dziejów średniowiecznej kultury, red. S. K. Kuczyński i in., Warszawa 1976, s. 403-412; por. J. Bieniak, Polska elita polityczna XII wieku (Część II. Wróżda i zgoda), w: Społeczeństwo Polski średniowiecznej. Zbiór studiów, t. 3, red. S.K. Kuczyński, Warszawa 1985, s. 13-74, tutaj s. 18-19.

${ }^{59} \mathrm{Z}$ najnowszej literatury np. J. Strzelczyk, Die Elemente des Lehnswesens im mittelalterlichen Polen, w: Patronage und Klientel, s. 45 n.; J. Kurtyka, Problem klienteli możnowładczej w Polsce późnośredniowiecznej, w: Genealogia. Władza i społeczeństwo w Polsce średniowiecznej, red. A. Radzimiński, J. Wroniszewski, Toruń 1999, s. 63.

${ }^{60}$ M. Friedberg, Klientela świecka biskupa krakowskiego $w$ w. XII-XIV. Ze studiów nad organizacja społeczeństwa w Polsce średniowiecznej, w: Studia historyczne ku czci Stanisława Kutrzeby,t. 1, Kraków 1938, s. 165-216, cytat s. 197-198.

${ }^{61}$ Ibidem, s. 198.

${ }^{62}$ J. Strzelczyk, op. cit., s. 46. 
się uwagę, że koncept „prawa feudalnego ministeriałów” pojawia się w źródłach w pełnym świetle dopiero od przełomu XII/XIII i w XIII w..$^{63}$ W przypadku adaptowania w Polsce przynajmniej pewnych elementów instytucji ministerialitetu musiałoby to znaleźć odzwierciedlenie w materiale źródłowym. Jak zobaczymy, tak właśnie było w ówczesnych Czechach/na Morawach. W konkluzji wypada podkreślić, że pytanie, czy istniał ministerialitet w Polsce w XII-XIII w., pozostaje na razie otwarte.

Wydaje się, że w takich badaniach najbardziej obiecujące byłoby wykorzystanie materiału źródłowego śląskiego. Wolno bowiem zakładać, że skoro na Śląsku doszło do recepcji prawa lennego (o tym dalej), to podobnie mogło być z prawem ministeriałów (dworskim). Tytułem przykładu zwróćmy uwagę na dokument księcia śląskiego Bolesława II Rogatki z 1252 r. potwierdzający nadanie jego stolnikowi Radwanowi 100 łanów koło Legnicy: „fideli nostro [- $]$ iure et titulo pheodali possidenda et habenda libere et absque omni onere servitutis, prout alii nostri nobiles et pheodales bona sua possident" "W . Wątpliwe, aby Radwan, zasadźca i wójt Legnicy, wywodził się z nobilów ${ }^{65}$, niemniej jednak otrzymał od księcia lenno "szlacheckie”. Sformułowanie „libere et absque omni onere servitutis” dotyczy najpewniej zwolnienia od płacenia czynszu oraz od służb, które nie przystoją nobilowi. Być może dyplom ten mówi pośrednio o lennach dworskich. Warto zwrócić uwagę także na dokument księcia wrocławskiego Henryka III Białego z 1263 r., gdzie są wymienieni „omnes milites, vasalli, feodales, nobiles" ${ }^{\prime 66}$. Milites i vasalli to zapewne grupa niższego rycerstwa, chciałoby się ich określić mianem ministeriałów, natomiast feodales i nobiles najpewniej należeli do grupy wyższej. Możliwa jest także odmienna identyfikacja: milites - rycerze na prawie polskim, vasalli - ministeriałowie, feodales i nobiles - posiadacze „prawdziwych”(tj. nie dworskich) lenn.

Wspomnieliśmy o recepcji prawa lennego na Śląsku. Istotny wkład w rozpoznanie tej problematyki dał przed bez mała dwiema dekadami T. Jurek ${ }^{67}$. Wykazał, że lenno pojawiło się w tej dzielnicy wraz z napływem niemieckich rycerzy, zwłaszcza od połowy XIII w. Informacje o lennach dotyczą prawie wyłącznie rycerzy niemieckich. Są też informacje o lennach niemieckich wójtów, sołtysów i chłopów. „Jeszcze w XIV w. za ewidentny uważano związek prawa lennego z Niemcami" ${ }^{68}$. Niecałe $20 \%$ przybywają-

${ }^{63}$ J. Keupp, Ministerialität und Lehnswesen. Anmerkungen zur Frage der Dienstlehen, w: Das Lehnswesen im Hochmittelalter, s. 349, 354, 356, 360.

${ }^{64}$ Schlesisches Urkundenbuch, t. 3: 1251-1266, wyd. W. Irgang, Köln-Wien 1984, nr 563.

${ }^{65}$ Por. M. Cetwiński, Radwan, PSB, t. 30, Wrocław 1987, szp. 1 n.

${ }^{66}$ Schlesisches Urkundenbuch, t. 3, nr 584.

${ }^{67}$ T. Jurek, Obce rycerstwo na Ślasku do połowy XIV wieku, Poznań 1996.

${ }^{68}$ Ibidem, s. 155. 
cych na Śląsk rycerzy było szlachcicami, reszta - ministeriałami. W drugiej połowie XIII w. rycerze niemieccy stanowili trzecią lub czwartą część rycerstwa śląskiego. Była względna równowaga między zamożnymi i niezamożnymi przybyszami. Rycerze otrzymywali odpowiednie uposażenie w ziemi i/lub w dochodach. Celem wędrówek były kształtujące się dwory książęce: „Opanowanie śląskich dworów przez obcy żywioł oznaczało, że już w ostatniej ćwierci XIII w. weszły one w świat kultury rycerskiej niemieckiej. [- - ] Śląsk stanowił [- - ] na swoim kierunku geograficznym najdalszą rubież owego niemieckiego świata rycerskiego"69. Tylko 13\% niemieckich rycerzy objęło urzędy - byli oni albo burgrabiami, albo sędziami dworskimi. Urzędy nie wyznaczały ścieżki kariery; wyróżnikiem pozycji społecznej był pas rycerski. „Na Śląsku [- - ] od schyłku XIII w. przestały się liczyć tradycyjne hierarchie urzędnicze [--], a właśnie noszenie pasa traktowano jako jeden z najistotniejszych wyznaczników prestiżu jednostki"70. Napływowi obcych rycerzy towarzyszyła degradacja dużej części rycerzy rodzimych. W parze z tym wszystkim ujawnia się silniejsza niż w innych dzielnicach władza książęca; jej podstawą były miasta lokowane na prawie niemieckim oraz lenne niemieckie rycerstwo ${ }^{71}$. Dopiero w ciągu XIV w. układ sił zmienił się na korzyść możnych.

T. Jurek podkreśla, że z punktu widzenia książąt prawo lenne było dużo bardziej atrakcyjne niż polskie prawo rycerskie ze względu na jakość służby wojskowej, zasady dziedziczenia nieruchomości, kontrolę nad funduszem ziemi ${ }^{72}$. Czy prawo lenne było również dla rycerzy korzystniejsze niż polskie prawo rycerskie? Autor nie wypowiada się na ten temat, skupia swoją uwagę raczej na rysujących się przed niemieckimi rycerzami widokach na awans majątkowy oraz na intensywne życie dworskie ${ }^{73}$. Warto jednak przywołać spostrzeżenia S. Reynolds, że w przypadku lenna rycerz mógł cieszyć się lepszą ochroną swojej własności, a także: „Kiedy rosły potęga i prestiż monarchii, hołd i obecność na dworze królewskim jawiły się jako naturalna manifestacja wierności, solidarności i naprawdę wysokiej pozycji. [- - Z Złożenie hołdu i objęcie lenna oznaczały uznanie zależności, ale był to zaszczytny rodzaj zależności, odmienny niż zależność chłopów"74.

${ }^{69}$ Ibidem, s. 147.

70 Ibidem, s. 131.

${ }^{71}$ Ibidem, s. 149.

${ }^{72}$ Ibidem, s. 155-156.

${ }^{73}$ Ibidem, s. 54, 56.

${ }^{74}$ "As the power and prestige of the monarchy increased, homage and attendance at the king's court seemed a natural manifestation of loyalty, solidarity, and indeed of high status. [- ] Doing homage and holding in fief meant an acknowledgement 
Rozważania T. Jurka każą postawić znak zapytania przy zaproponowanej przez S. Gawlasa odpowiedzi na pytanie, dlaczego w XIII w. nie doszło w Polsce do recepcji prawa lennego. Jak pamiętamy, w odpowiedzi tej został położony nacisk na działania książąt, którzy mieli obawiać się, że instytucja lenna może zostać wykorzystana przez możnych do realizacji ich odśrodkowych planów politycznych. Jednak na Śląsku prawo lenne posłużyło tamtejszym książętom jako narzędzie umocnienia ich władzy. Nasuwa się zatem domysł, że w pozostałych dzielnicach na przeszkodzie recepcji lenna stały odmienne przyczyny niż te, których domyśla się S. Gawlas.

Brak na większą skalę recepcji lenna w XIII stuleciu w Polsce poza Śląskiem ${ }^{75}$ należałoby rozpatrywać także $\mathrm{w}$ ramach analiz z zakresu wymiany społecznej, społecznej rzadkości zasobów oraz szeroko pojmowanej historii kultury. Wariantem wymiany społecznej jest gra. W systematyce gier zaproponowanej przez Rogera Caillois interesują nas dwie grupy: agon (przeważa w nim element współzawodnictwa i walki) oraz alea (dominuje w nim element przypadku, losu, dziedzictwa) ${ }^{76}$. W grupie pierwszej mieszczą się gry rycerskie - np. turnieje, a także związane z nimi rekwizyty - np. pas rycerski. Dla nas kluczowe jest stwierdzenie autora, że „najistotniejsze i najbardziej złożone przejawy [kultury M.D.] okazują się ściśle związane ze strukturami gier i zabaw, a nawet w ogóle jawią się jako struktury zabawowe [--] przeistoczone w instytucje, w systemy norm prawnych, przekształcone w struktury kategoryczne, władcze, niezastąpione, krótko mówiąc, wyniesione do zasad gry społecznej"77.

Pojawienie się lenna na Śląsku może być też interpretowane jako odzwierciedlenie przyjmowania nowej kultury, związanej z odmiennymi zasadami wymiany (gry) społecznej. Była to kultura agonu; jej nosicielami byli przybywający na Śląsk rycerze-Niemcy. W warunkowym dzierżeniu ziemi (lennie) zawarta jest idea maksymalnego wysiłku. T. Jurek zestawia informacje, jak w Polsce postrzegano rycerzy niemieckich: niezwyciężeni

of subordination, but it was an honourable kind of subordination, distinct from that of peasants", S. Reynolds, Fiefs and Vassals, s. 278-279.

${ }^{75}$ Pewnym wyjątkiem była Wielkopolska, potrzebne są tutaj dalsze badania. Por. S. Gawlas, Die Probleme des Lehnswesens, s. 121. Z pogranicza fantastyki historycznej jest pogląd sformułowany przez Jerzego Dowiata (Polska - państwem średniowiecznej Europy, Warszawa 1968, s. 219-220), o „klasycznej strukturze feudalnej” i wielostopniowej „drabinie feudalnej” w Polsce XIII w.

${ }^{76}$ R. Caillois, Gry i ludzie, Warszawa 1997 (oryg. franc. 1967), rozdz. 2.

${ }^{77}$ Ibidem, s. 62. Odwoływanie się do teorii gier R. Caillois może wydawać się ryzykowne; warto jednak wziąć pod uwagę stwierdzenie N. Eliasa (Czym jest socjologia?, Warszawa 2010 (oryg. niem. 2004), s. 90) dotyczące gier: „Jest to elementarna sytuacja, którą spotykamy wszędzie tam, gdzie ludzie wchodzą ze sobą w relacje, ale którą często wypieramy podczas namysłu nad relacjami międzyludzkimi” (rozdz. 3: „Modele gry”). 
w walce, najwierniejsi, najgorliwsi w służbie ${ }^{78}$. Kultura agonu koncentrowała się na dworach książąt śląskich.

W kulturze rycerzy polskich na Śląsku przeważała alea - na czele skali wartości były przynależność rodowa i urzędy ziemskie, a nie dwór i kultura rycerska. Masowy napływ rycerzy niemieckich, trzymających się razem, monopolizujących udział w życiu dworskim, siłą rzeczy zamykał większości polskich rycerzy możliwość poznania tej nowej kultury. Zresztą była ona z natury rzeczy nieosiągalna dla ubogich „rycerzyków” czy osób „mających się za rycerzy", znanych z Księgi Henrykowskiej. Instytucja lenna pozwoliła rozwiązać problem społecznej rzadkości zasobów (ziemi) na Śląsku, jaki pojawił się wraz z napływem rycerzy niemieckich, mianowicie miejscowym rycerzom pozostało kontentowanie się majątkami ziemskimi na pełną własność, co było równoznaczne z przegraniem przez nich rywalizacji o pozycję społeczną.

Powstaje pytanie o wspomniane wyżej lenna chłopskie, mieszczańskie, sołtysie $^{79}$. Jak interpretować te pojęcia? Kazimierz Tymieniecki pisał, że „lenna-łany niosły ze sobą [- ] cały szereg [- - ] urządzeń z zachodnim prawem lennym związanych" ${ }^{80}$. Stanisław Russocki wyraził pogląd, że „zarówno władztwo gruntowe i poddaństwo, jak też system lenny stanowiły jedynie pewne aspekty, elementy określonej, globalnej struktury" ${ }^{\prime 1}$.K. Modzelewski zwracał uwagę na recepcję prawa niemieckiego jako zamknięcie feudalizacji ustroju w Polsce ${ }^{82}$. Z kolei Antoni Mączak, wskazując na analogie między lennem rycerskim i dzierżeniem chłopskim, postulował szerszą interpretację feudalizmu, obejmującą nie tylko system lenny, lecz także analogie „między strukturą klasy panującej (rycerstwa) a formami dzierżenia chłopskiego", wreszcie - szeroko pojęty system produkcji ${ }^{83}$.Jan M. Piskorski opowiada się za teorią, że „z frankijskiego beneficjum wywodziło się lenno rycerskie i lenno chłopskie” ${ }^{4}$. Zdaniem Janusza Kurtyki w „Polsce najpowszechniejszymi elementami systemu lennego stały się lenna nie-

${ }^{78}$ T. Jurek, Obce rycerstwo na Śląsku, s. 136-137.

${ }^{79}$ Ibidem s. 154-155.

${ }^{80}$ K. Tymieniecki, Lenna chłopskie czy prawo niemieckie?, RH 20, 1951-1952, s. 59-120, cytat s. 113; zob. także inne prace tego autora. W ślad za poglądami K. Tymienieckiego szedł J. Dowiat, op. cit., s. 215-219.

${ }^{81}$ S. Russocki, Rola ,fidelitas" i ,beneficium" w ustroju państw słowiańskich, w: Z polskich studiów slawistycznych, seria 4: Historia, red. J. Bardach i in., Warszawa 1972, s. 67.

${ }^{82} \mathrm{~K}$. Modzelewski, Organizacja gospodarcza państwa piastowskiego X-XIII wiek, Poznań 2000, s. 225 n.

${ }^{83}$ A. Mączak, Rządzacy i rządzeni. Władza i społeczeństwo w Europie wczesnonowożytnej, Warszawa 1986, s. 14-15.

${ }^{84}$ J. M. Piskorski, Kolonizacja wiejska Pomorza Zachodniego w XIII i w poczatkach XIV wieku na tle procesów osadniczych w średniowiecznej Europie, Poznań 1990, s. 69-70. 
szlacheckie: sołectwa [- - ] i łany kmiece [- - ]. Lenna rycerskie stanowiły margines wobec szlacheckich dóbr alodialnych" 85 . W historiografii niemieckiej pół wieku temu W. Ebel zwrócił uwagę na nadrzędną kategorię „Leihe”, obejmującą lenno rycerza, ministeriała, chłopa itp..$^{86}$ Ostatnio Gertrud Thoma wyraża pogląd, że stosunek lenny występował w wielu kontekstach, a nie tylko w związku z wasalstwem ${ }^{87}$. Z kolei B. Kasten, nawiązując do poglądów W.Ebela, stawia na jednej płaszczyźnie lenno rycerskie i czynszowe dziedziczne gospodarstwo chłopskie (zinsrechtliche Erbleihe) ${ }^{88}$. W perspektywie chociażby historii kultury teoria o lennie chłopskim jako podstawie feudalizmu w Polsce nie wydaje się przekonująca. Feudalizmowi była właściwa, jak mówiliśmy, kultura agonu; chłopi w tej kulturze nie uczestniczyli. Koncept Leihe nie jest w stanie zasypać przepaści miedzy lennem rycerskim i lennem chłopskim. Warto tutaj wspomnieć, że w Zwierciadle saskim, powiada się, że chłopi, tak jak wszyscy inni, którzy nie są rycerzami z ojca i dziada, nie powinni korzystać z prawa lennego ${ }^{89}$.

Zagadnienie lenna w Polsce w późnym średniowieczu to osobny problem. Zdaniem S. Gawlasa w odnowionym Królestwie nie mogło być mowy o zastosowaniu relacji lennych z uwagi na, z jednej strony, polityczną dominację rycerstwa, jego wewnętrzną konsolidację, prawne ujednolicenie, posiadanie ziemi na pełną własność z atrakcyjnym prawem dziedziczenia; $z$ drugiej strony, na przeszkodzie takiej recepcji stało to, że władca dysponował bezpośrednią zwierzchnością nad rycerstwem oraz że nie powstały władztwa terytorialne świeckie bądź duchowne ${ }^{90}$.

Nie ma co zaprzeczać istnieniu i oddziaływaniu tych czynników. Jednak takie „kalkulacyjne” (por. wyżej) podejście do problemu nie może w pełni zadowalać. Pytanie o typ wymiany (gry) społecznej: agon czy alea, nie traci swojej doniosłości także odnośnie do późnego średniowiecza polskiego. Warto tutaj wspomnieć, że podobna kwestia była już stawiana, jednak - o ile nam wiadomo - nie zainicjowało to szerszej

${ }^{85}$ J. Kurtyka, op. cit., s. 66; idem, Odrodzone Królestwo. Monarchia Władysława Łokietka i Kazimierza Wielkiego w świetle nowszych badań, Kraków 2001, s. 155-156, 187, 196.

${ }^{86}$ W. Ebel, Über den Leihegedanken in der deutschen Rechtsgeschichte, w: Studien zum mittelalterlichen Lehenswesen, Lindau-Konstanz 1960, s. 11-36.

${ }^{87}$ G. Thoma, Leiheformen zwischen Grundherrschaft und Lehnswesen, w: Das Lehnswesen im Hochmittelalter, s. 386; por. H. Seibert, Non predium, sed beneficium esset... Das Lehnswesen im Spiegel der bayerischen Privaturkunden des 12. Jahrhunderts (mit Ausblicken auf Tirol), w: Das Lehnswesen im Hochmittelalter, s. $152 \mathrm{nn}$.

${ }^{88}$ B. Kasten, Zum Gedankengut der Fürstenerhebungen.

${ }^{89}$ „dorpere [- $]$ unde alle de nicht ne sin van ridderes art van vader unde van eldervader, de scolen lenrechtes darven", Sachsenspiegel II. Lehnrecht, wyd. K. A. Eckhardt, Aalen 1973, 2 § 1, s. 19.

${ }^{90}$ S. Gawlas, Die Probleme des Lehnswesens, s. 121-122. Por. J. Kurtyka, Odrodzone Królestwo, s. 48-154. 
dyskusji. Przed bez mała ćwierćwieczem Antoni Gąsiorowski pisał, że z dwóch podstawowych dróg do poważnych stanowisk w polskim społeczeństwie szlacheckim u schyłku średniowiecza, „tj. dziedzictwa oraz własnego trudu, trzeba przypisać obydwu duże znaczenie. Dziedziczenie tytułu do majątku i prestiżu jest powszechnie doceniane w badaniach nad polskim rycerstwem średniowiecznym; wydaje się jednak, że druga droga, która dawała sposobność do awansu, dotychczas zbyt często była lekceważona"91.

Miernikiem intensywności relacji wymiany społecznej mieszczącej się w grupie agonu mogą być informacje na temat pasowania rycerskiego. W Polsce tytulatura rycerzy pasowanych pojawia się na szerszą skalę w drugiej połowie XIV w., ale do końca średniowiecza hierarchia urzędu była ważniejsza niż hierarchia pasa rycerskiego. Pasowanie w niewielkim zakresie przyczyniało się do kariery. Jest tutaj widoczny kontrast ze Śląskiem, gdzie hierarchia pasa rycerskiego stała na pierwszym planie ${ }^{92}$. Turnieje rycerskie pojawiły się w Polsce (poza Śląskiem) szerzej dopiero od schyłku XIV w..$^{93}$ Migracja rycerzy obcych była relatywnie niewielka, przybyszom trudno było zrobić karierę na dworze królewskim ${ }^{94}$. Słabość kultury rycersko-dworskiej w Polsce średniowiecznej nie ulega wątpliwości ${ }^{95}$. Tymczasem między kulturą rycersko-dworską i feudalizmem lennym istniało sprzężenie zwrotne. Słabość kultury rycerskiej nasta-

91 „Von den zwei grundlegenden Wegen [--] [zu wichtigen Posten in der polnischen Adelsgesellschaft gegen Ende des Mittelalters - M.D.], d.i. des Erbens und der eigenen Bemühung, muß man beiden große Bedeutung beimessen. Das Erben des Titels auf Vermögen und Prestige wird in den Forschungen über den mittelalterlichen polnischen Ritterstand breit anerkannt; es scheint jedoch, daß der zweite Weg, der Möglichkeiten eines Aufstiegs bot, bisher allzu oft unterschätzt wurde", A. Gąsiorowski, Faktoren der Schichtung des Adelsstandes im mittelalterlichen Polen, „Quaestiones Medii Aevi" 4, 1991, s. 87-115, cytat s. 115.

92 Zob. ostatnio A. Szymczakowa, Milites strenui z Sieradzkiego w XV w., w: Genealogia. Rola związków rodzinnych i rodowych $w$ życiu publicznym $w$ Polsce średniowiecznej na tle porównawczym, red. A. Radzimiński, J. Wroniszewski, Toruń 1996, s. 191-214 - tam literatura; D. Piwowarczyk, Obyczaj rycerski w Polsce późnośredniowiecznej (XIV-XV wiek), Warszawa 1998, s. 44 n.

${ }^{93}$ B.W. Brzustowicz, Turniej rycerski w Królestwie Polskim w późnym średniowieczu i renesansie na tle europejskim, Warszawa 2003.

${ }^{94}$ Zob. ostatnio T. Jurek, Obce rycerstwo $w$ średniowiecznej Wielkopolsce, w: Wielkopolska - Polska - Europa. Studia dedykowane pamięci Alicji Karłowskiej-Kamzowej, red. J. Wiesiołowski, Poznań 2006, s. 45-56.

${ }_{95}$ Zob ostatnio W. Iwańczak, Höfische Kultur und ritterliche Lebensformen in Polen vor dem Hintergrund der europäischen Entwicklung, w: Das Reich und Polen, red. A. Patschovsky, T. Wünsch, Ostfildern 2003, s. 277-300; idem, Rola i znaczenie dwóch kręów cywilizacyjnych. Slavia Occidentalis i Slavia Orientalis w dziejach Europy Środkowowschodniej (okcydentalizacja i bizantynizacja regionu), w: Europa Środkowowschodnia od X do XVIII wieku, s. 104-105. 
wionej na współzawodnictwo jest wskaźnikiem, że problem społecznej rzadkości zasobów (ziemi) dotyczył drobnego rycerstwa nieporównanie słabiej niż w krajach feudalnych; pomogło to temu rycerstwu obronić się przed degradacją społeczną i wejść w szeregi szlachty.

W literaturze przedmiotu da się wyodrębnić pewną liczbę kwestii dotyczących lenna w Polsce późnego średniowiecza, z których tutaj zasygnalizujemy cztery.

Po pierwsze, chodzi o tzw. lenna/maństwa na Rusi Czerwonej i na Podolu. Antoni Prochaska, autor podstawowej pracy ten temat, chyba zbyt pochopnie nadał tym majątkom rycerskim mocną lenną interpretację, dopatrzył się istnienia feudalizmu (litewsko-)ruskiego itp. ${ }^{96} \mathrm{~J}$. Kurtyka słusznie zauważył: „Skala rozpowszechnienia systemu lennego na Rusi Czerwonej i Podolu wciąż wymaga dyskusji (z wykorzystaniem nowszych edycji źródeł)" ${ }^{\prime}$. Z kolei S. Russocki miał rację, pisząc w odniesieniu do tego obszaru o systemie nadań „zbliżonych do lenn”; inna sprawa, że zupełnie niepotrzebnie próbował adaptować przy tej okazji teorię Ottona Hintzego o feudalizmie jako narzędziu realizacji celów imperialnych w warunkach gospodarki naturalnej ${ }^{98}$. Dodajmy, że wywody A. Prochaski o lennym feudalizmie na Litwie są zupełnie przestarzałe ${ }^{99}$.

Po drugie, jeśli chodzi o „lenna” rycerskie w Wielkopolsce, na uwage zasługują badania T. Jurka, który wykazał konieczność eksploracji bazy źródłowej w poszukiwaniu nowych informacji, konkludując, że w Wielkopolsce lenna nie były, ,,jak się zwykło sądzić, egzotyczną osobliwością"100.

Po trzecie, rewizji wymaga pogląd dość powszechny w naszej historiografii, że w Polsce późnośredniowiecznej (hierarchiczne) struktury

${ }^{96}$ A. Prochaska, Lenna i maństwa na Rusi i na Podolu, RWHF PAU, seria 2, t. 17 (42), 1902, s. 1-30.

${ }^{97}$ J. Kurtyka, Problem klienteli możnowładczej, s. 104; idem, Enfeoffment and Clientship in the Late Medieval Kingdom of Poland: the Case of Red Ruthenia (Rus'), "Quaestiones Medii Aevi Novae" 5, 2000, s. 267-278.

${ }^{98} \mathrm{~S}$. Russocki, Instytucje - wpływy - kultura: warunkowe nadania ziemi w procesie centralizacji feudalnych monarchii środkowo-wschodniej Europy późnego średniowiecza, „Przegląd Humanistyczny” 28, 1984, 1 (220), s. 7 n., 11 n.; por. idem, Rola ,fidelitas" i ,beneficium", s. 82.

${ }^{99} \mathrm{~W}$ sprawie najnowszej dyskusji o feudalizmie na Litwie zob. R.R. Trimonienè, Badania nad społeczeństwem Wielkiego Księstwa Litewskiego. Aktualne problemy, w: Historia społeczna późnego średniowiecza. Nowe badania, red. S. Gawlas, Warszawa 2011, s. 52-54; Lidia Korczak (Monarcha i poddani. System władzy w Wielkim Księstwie Litewskim w okresie wczesnojagiellońskim, Kraków 2008, s. 147-149, 153) pisze o klienteli uposażonej w ziemię o charakterze lenna.

100 T. Jurek, Omagialitas alias manowstwo, s. 270. Z prac T. Jurka dotyczących lenna w Wielkopolsce zob. też idem, Starostwo wschowskie w latach 1343-1422, w: Homines et societas. Czasy Piastów i Jagiellonów. Studia historyczne ofiarowane Antoniemu Gąsiorowskiemu w sześćdziesiąta piąta rocznicę urodzin, red. J. Bieniak i in., Poznań 1997, s. 241-253. 
rodowe zastępowały „drabinę feudalną" ${ }^{101}$. Relacje wymiany społecznej feudalne i relacje wymiany społecznej rodowe nie mogą siebie zastępować z racji swojej odrębnej natury; pierwsze mieszczą się w grupie agon, drugie - w grupie alea. W Polsce brakowało wymiany społecznej feudalnej, nastawionej na współzawodnictwo, i trzeba postawić pytanie o konsekwencje tego zjawiska.

Po czwarte wreszcie, rewizji wymaga pogląd wyrażony przez K. Tymienieckiego i rozwinięty przez Jacka S. Matuszewskiego o lennym (feudalnym) charakterze zastawów (królewszczyzn) ${ }^{102}$. Nie słyszymy o tym, aby zastawnik przyjmował od zastawcy dobra zastawne w lenno, tak jak praktykowano chociażby w Królestwie Czech.

Chronologia i pochodzenie feudalizmu w Czechach i na Morawach są w historiografii sporne. Istnieje pogląd o jego wczesnej (XI-XII w.) metryce i rodzimej genezie. W świetle współczesnej dyskusji o feudalizmie w Europie Zachodniej jest to punkt widzenia nie do obrony. Istnieje także opinia o datowaniu tego feudalizmu na wiek XIII i o jego pochodzeniu z Niemiec ${ }^{103}$.

W najnowszej historiografii o rodzimej genezie feudalizmu w Czechach/na Morawach mówią Josef Žemlička oraz Libor Jan. Zwracają oni uwagę na nadania w XI-XII w. nomine beneficii lub nomine suppe. Inna sprawa, że każdy z tych uczonych inaczej interpretuje naturę tych nadań. Zdaniem J. Žemlički termin beneficium oznaczał uposażenie urzędnika terytorialnego częścią dochodów z danego urzędu płynących do kasy władcy. Poza tym urzędnik mógł posiadać dziedziczny rodowy majątek ziemski. Autor daje taki komentarz: „System beneficjalny zbliżał się do klasycznych stosunków lennych europejskiego Zachodu dwukierunkowym stosunkiem służby i wynagrodzenia. Wszakże oddalał się od nich z racji dwóch cech. Urzędnicze beneficjum nie miało formalnie dziedzicznego charakteru. [- - ] Dobrodziejstwo, beneficjum (później

${ }^{101}$ Np. S. Gawlas, Die Probleme des Lehnswesens, s. 116 nn.

102 K. Tymieniecki, Wpływy ustroju feudalnego w Polsce średniowiecznej, RDSG 3, 1934, s. 104-109; zob. także inne prace tego autora. J. S. Matuszewski, Obowiazzek służby wojskowej zastawników królewszczyzn w piętnastowiecznej Polsce, CPH 34, 1982, 1, s. 101-113.

${ }_{103}$ Zob. przegląd literatury: J. Žemlička, Čechy v době knižecí (1034-1198), Praha 1997, s. 470 n., przyp. 134; K. Kowalewski, Rycerze, włodycy, panosze. Ludzie systemu lennego w średniowiecznych Czechach, Warszawa 2009, s. $5 \mathrm{nn}$. W polskiej historiografii opinia o rodzimej genezie feudalizmu w Polsce średniowiecznej pojawia się sporadycznie. Po ostatniej wojnie wyrażał ją bodajże tylko J. Dowiat (op. cit., s. 201-206): ,instytucje analogiczne do lennych tworzyły się u nas drogą naturalnego, samodzielnego rozwoju". 
stosowane jest także słowo suppa, żupa) początkowo nie dotyczyło uposażenia z konkretnych dochodów gruntowych i z regaliów, a raczej wynagrodzenia, które miało przypaść temu czy innemu urzędowi z sumy dochodu zebranego w danym okręgu. W porównaniu z Zachodem, gdzie treść kontraktów lennych stanowiły majątki ziemskie i prawa nad ludźmi, w Czechach właśnie owe udziały bywały «wynagrodzeniem». Wolno mówić o jakimś państwowym feudalizmie, który w różnych formach splatał się z całym społeczeństwem" ${ }^{104}$. Zaskakuje odwoływanie się do kategorii „państwowego feudalizmu”, przejętej chyba z sowieckiej historiografii ${ }^{105}$

Z kolei L. Jan powiada, że termin beneficium/suppa mógł dotyczyć urzędu, czasowego ziemskiego uposażenia urzędu lub czasowego nadania ziemskiego nie związanego z urzędem, i przypomina wyrażony bez mała wiek temu pogląd Josefa Šusty, że w Czechach pojawiały się wcześnie tendencje „do prawdziwego feudalizmu” („,k opravdovému feudalizmu"), jednak rozwój prawa ziemskiego uniemożliwił ich pełny rozwój ${ }^{106}$.

104 „Dvousměrným poměrem služby a odměny se beneficiární systém blížil klasickým lenním vztahům evropského západu. Dvěma rysy se jim však vzdaloval. Úřednické beneficium nemělo formálně dědičný ráz. [- - ] Dobrodiní, beneficium (později se užívá rovněž výrazu suppa, župa) se zprvu nevázalo ani tak na požitky z konkrétních pozemkových a regálových výnosů, jako spíše na př́ijmy, které měly tomu nebo jinému úřadu připadnout ze sumy důchodů, vybraných v daném obvodu. Ve srovnání se západem, kde náplň lenních úmluv tvořily pozemkové majetky a práva nad lidmi, bývaly v Čechách «odměnou» právě tyto podíly. Je možné mluvit o jakémsi státním feudalismu, který v různých formách protkával celou společnost”, J. Žemlička, op. cit., s. 187; ponadto idem, Počátky Čech královských 1198-1253. Proměna státu a společnosti, Praha 2002, s. 41; idem, Kasteláni, vilikové a beneficia v netransformované transformaci, „Český časopis historický" 106, 2008, 1, s. 128 nn.

${ }^{105}$ Zob. zwłaszcza L. V. Čerepnin, Osnovnye ètapy razvitiâ feodal'noj zemel'noj sobstvennosti na Rusi (do XVII v.), „Voprosy istorii” 1953, 4, s. 38-63; idem, Obrazovanie Russkogo centralizovannogo gosudarstva $v$ XIV-XV vekah. Očerki social'no-èkonomičeskoj i političeskoj istorii Rusi, Moskva 1960; idem, Rus'. Spornye voprosy istorii feodal'noj zemel'noj sobstvennosti v IX-XV vv., w: A.P. Novosel'cev, V.T. Pašuto, L. V. Čerepnin, Puti razvitiâ feodalizma (Zakavkaz'e, Srednââ Aziâ, Rus', Pribaltika), Moskva 1972, s. 126-251. Warto tutaj wspomnieć, że we wczesnych pracach K. Modzelewskiego, miarodajnych dla sformułowania modelu wczesnośredniowiecznego państwa typu środkowo-wschodnioeuropejskiego, nie znajdujemy pojęcia „feudalizmu państwowego”; sporadycznie jest mowa o „elementach feudalno-państwowych”, w znaczeniu gospodarki „książęco-państwowej" - zob. idem, Z badań nad organizacją stużebna w Polsce wczesnofeudalnej, KHKM 9, 1961, 4, s. 729, przyp. 88. W publikacjach od początku lat siedemdziesiątych K. Modzelewski promował pojęcie „poddaństwa państwowego” - zob. idem, Organizacja gospodarcza państwa piastowskiego, rozdz. 3 (1 wyd. 1975); idem, The System of the Ius Ducale, s. 75, 81, 90 nn.

${ }^{106}$ L. Jan, Václav II. a struktury panovnické moci, Brno 2006, s. 184; por. D. Třeštík, J.Žemlička, O modelech vývoje přemyslovského státu, „Český časopis historický” 105, 2007, 1, s. 122-163, tutaj s. 139 nn. 
Cytowany autor przywołuje informację podaną przez Kosmasa pod rokiem 1073 o Komboldzie, mieszczaninie z Ratyzbony, rycerzu biskupa Jaromira-Gebharda, który posiadał odeń „annuatim [- ] beneficium XXX marcas argenti" (II 28), a także o komesie Rapocie, który otrzymał od księcia Wratysława 150 grzywien srebra „annuatim pro beneficio" (II 29), jednak nie da się obronić wniosku, że chodzi tutaj o „prawdziwe lenno” („opravdové léno”) ${ }^{107}$. Po ukazaniu się książki S. Reynolds trzeba być ostrożnym z lenną interpretacją wczesnośredniowiecznych beneficjów ${ }^{108}$. Ostatnio B. Kasten prezentuje pogląd, że wczesnośredniowieczne nadania (ziemi) iure beneficii dotyczyły czasowego użytkowania nadanego obiektu; wyróżnia także beneficja w znaczeniu lenn bez osobistego wasalstwa posiadacza takiego beneficjum ${ }^{109}$.

L. Jan zwraca uwagę na Henryka z Kuenringu, z austriackich ministeriałów, który w 1265 r. został określony jako „suppanus” Witrah („Hainrico suppano de Witrah, marschalco Austrie") ${ }^{110}$. Otóż jego przodek Hadmar miał otrzymać w 1185 r. od księcia Bedrzycha, syna Władysława II, Vitoraz (Weitra) na pograniczu z Austrią jako lenno; w dokumencie książę deklaruje: ,iure beneficii concessimus et sine contradictione infeudavimus” ${ }^{111}$. L. Jan komentuje ten zapis: „Połączenie wyrazowe «iure beneficii concedere» zostało tutaj jednoznacznie przytoczone jako synonim dla słowa "infeudare»"112. Zaproponowana interpretacja budzi wątpliwości. $\mathrm{Na}$ to, że sformułowania: iure beneficii concedere oraz infeudare nie są synonimami, wskazuje implicite klauzula: sine contradictione. Pojawiła się ona zapewne dlatego, że infeudacja była czynnością dodatkową, która z reguły nie towarzyszyła nadaniom iure beneficii. Powstaje pytanie, jak interpretować czasownik infeudare. Sformułowanie w tekście dokumentu: „hominii et fidelitatis iure [- - ] eum [Hadmarum] nobis fidelitatis

${ }^{107}$ L. Jan, op. cit., s. 223 i przyp. 236; por. D. Třeštík, J. Žemlička, op. cit., s. 142.

108 Por. S. Reynolds, Fiefs and Vassals, rozdz. 4.2. W starszej literaturze Wilhelm Weizsäcker (Lehnswesen in den Sudetenländern, w: Studien zum mittelalterlichen Lehenswesen, s. 229-234, tutaj s. 229) wypowiedział się o czeskich beneficjach, że były to „Keimund Vorformen" poprzedzające i ułatwiające recepcję lenna.

${ }^{109}$ B. Kasten, Beneficium zwischen Landleihe und Lehen - eine alte Frage, neu gestellt, w: Mönchtum - Kirche - Herrschaft 750-1000, wyd. D. R. Bauer i in., Sigmaringen 1998, s. 242-260, zwł. s. 254-257; eadem, Das Lehnswesen - Fakt oder Fiktion?, w: Der frühmittelalterliche Staat - europäische Perspektiven, red.W. Pohl, V. Wieser, Wien 2009, s. 331-353, zwł. s. 335-345.

110 Codex diplomaticus et epistolaris regni Bohemiae (dalej: CDB), t. 5, cz. 1, wyd. J. Šebánek, S. Dušková, Pragae 1974, nr 438.

111 CDB, t. 1, wyd. G. Friedrich, Pragae 1904-1907, nr 309.

112 „Zde je jednoznačně spojení «iure beneficii concedere» uvedeno jako synonymum s «infeudare»”, L. Jan, op. cit., s. 184; zob. też J. Žemlička, Přemysl Otakar II. Král na rozhraní věkü, Praha 2011, s. 218 n. 
debito astringere curavimus" 113 , wskazuje, że Hadmar został zobowiązany do złożenia przysięgi wierności. Może to nadanie było dziedziczne i stąd pojawił się wymóg złożenia przysięgi; beneficja były nadaniami czasowymi, zatem taka przysięga nie musiała być wymagana. Co do terminu hominium, nie musiał on odnosić się do hołdu lennego ${ }^{114}$. Czy Hadmar miał świadczyć jakieś służby na rzecz Bedrzycha - nie wiadomo. W każdym razie domysł L. Jana, że posiadacze beneficjów mogli składać sui generis lenną przysięgę ${ }^{115}$ jest nie do utrzymania.

Tak czy inaczej, interesujący nas dokument jest świadectwem recepcji w Czechach/na Morawach w końcu XII w. pewnych elementów wokabularza feudalnego. Zwraca uwagę szybkie tempo tej recepcji; prawo lenne (zwyczajowe saskie oraz uczone z Italii) pojawia się w czołowych regionach Rzeszy w późnym XII w. ${ }^{116}$

Jak można by sklasyfikować nadanie Vitorazu? Infeudacja sprowadzała się najprawdopodobniej do ceremonii złożenia przysięgi wierności. Może zatem trafnie byłoby mówić o beneficjum z przysięgą wierności? Takich nadań beneficjalnych mogło być więcej, o czym świadczą chociażby dwa dokumenty Przemysła Otokara I z 1228 r. zawierające sformułowanie: ,beneficiarios nostros a nobis infeudatos"117. L. Jan pisze w związku z tym: „posiadacze królewskich beneficjów są tutaj określeni jednoznacznie: infeudati, a zatem jako ci, którym nadano lenno - niewątpliwie ich uposażenie beneficjalne"; i dodaje, że beneficja czeskie przypominają beneficja karolińskie $^{118}$.

${ }^{113}$ Por. też narrację w omawianym dyplomie, CDB, t. 1, nr 309: „Dignitati principum et paci conservande indubitanter expedire cognovimus, ut quos infra terminos sue potestatis debito hominio et fidelitatis iure tenent astrictos, non tantum ad sua obsequia requirant, verum etiam vicinos, quos fidei sue sinceritas commendat, liberali beneficientia sibi obligare studeant".

114 S. Reynolds, Fiefs and Vassals, s. 262, 269 nn.; ostatnio Ch. West, op. cit., s. 209 n.: „homage was a convenient label for a ceremony instituting a specially binding relationship between aristocrats of different rank, in a way which went beyond a mere oath".

${ }^{115}$ L. Jan, op. cit., s. 223 i por. s. 225.

116 Zob. ostatnio J. Dendorfer, Das Lehnrecht und die Ordnung des Reiches. «Politische Prozesse» am Ende des 12. Jahrhunderts, w: Ausbildung und Verbreitung des Lehnswesens, s. 187-190; S. Patzold, op. cit., s. 271-272, 295; K. Andermann, Verbreitung, Strukturen und Funktion des Lehnswesens im Umkreis von Fürsten, Grafen, Herren und Prälaten vom 11. bis in die Mitte des 13. Jahrhunderts, w: Ausbildung und Verbreitung des Lehnswesens, s. 311-312.

117 CDB, t. 2, wyd. G. Friedrich, Pragae 1912, nr 320, 321; por. D. Třeštík, J. Žemlička, op. cit., s. 141. Z 1220 r. pochodzi dokument Konrada, komesa „de Hardeke”, zawierający informację o tym, że „miles Bertherus nomine a nobis fuit infeudatus de [- - ] villa, que vocatur Scorscicz" (CDB, t. 2, nr 197). Niekiedy traktuje się ją jako najstarszy przekaz o lennie w Czechach/na Morawach. Być może chodzi tutaj o beneficjum z przysięgą.

118 „Královští beneficiáři zde jsou jednoznačně «infeudati», tedy, ti, kteř́i jsou obléněni - nepochybně výbavou svých beneficií”, L. Jan, op. cit., s. 189. 
Warto w tym miejscu zwrócić uwagę na passus z dokumentu wystawionego przez Roberta, biskupa ołomunieckiego, dla Rudgera, „magistra” szpitala Św. Ducha w Brnie, z 1238 r.: ,ne [- - ] exigat ulla secularis ęcclesiasticave persona fidelitates, hominia, iuramenta vel securitates reliquas, quę a laicis frequentantur" 119 . Wymienione tu terminy (,fidelitates, hominia, iuramenta vel securitates reliquas") są określeniami różnych przysiąg. Zróżnicowanie tej nomenklatury może oznaczać, że przysięgi, w tym przysięgi wierności, stały się wówczas ważnym sposobem formalizowania relacji społecznych i środkiem tworzenia zaufania. W świetle przytoczonego fragmentu dokumentu biskupa Roberta tym bardziej utwierdzamy się w przekonaniu, że nadanie Vitorazu nie miało charakteru lennego; formalnym umocowaniem tej donacji były natomiast ius beneficii oraz ius hominii et fidelitatis.

Nadania beneficjów iure feodali spotykamy także w drugiej połowie XIII w. Np. w testamencie Voka z Rožmberka z 1262 r. czytamy: „Item Gvilloni in Emerndorf quatuor beneficia contuli iure et tytulo feodali" ${ }^{120}$.

Z roku 1229 pochodzi dokument wyszehradzkiej kapituły katedralnej dotyczący nadania dóbr Zděnice Henrykowi Sasowi (Saxoni), w którym czytamy: „homagium recipientes, bona [- - ] iure feodali concessimus $[--]$ tali forma, quod $\mathrm{v}$ annis eadem libere bona possideat et extunc singulis annis ecclesie nostre marcam et dimidium persolvat [- - ] Ceterum, cum dictus Heinricus homagium ecclesie nostre faceret, firmiter repromisit, quod in prefatis bonis duas villas institueret" ${ }^{121}$. Można by zakładać, że mamy tutaj do czynienia z nadaniem lennym - wspomina się ius feudale i homagium. Zwraca jednak uwagę czynsz, jaki Henryk miał płacić kapitule po pięcioletniej wolniźnie. Tymczasem w Zwierciadle saskim jest przepis, że dobra obciążone czynszem nie mogą stać się lennem ${ }^{122}$. Nasuwa się wniosek, że Henryk Sas otrzymał jakieś lenno dworskie (tj. lenno ministeriała), a nie prawdziwe lenno. W zamian za to złożył przysięgę wierności (homagium) z zastosowaniem jakiegoś ceremoniału, a także dodatkowo przyrzekł, że lokuje dwie wsie (najpewniej zasiedlone Niemcami). Nadanie dla Henryka Sasa miało wyraźny aspekt kolonizacyjny.

W każdym razie na podstawie analizy powyższych dokumentów nasuwa się wniosek, że beneficja infeudowane, tj. z obowiązkiem złożenia przez beneficjenta przysięgi wierności, mogły być nadawane dziedzicznie (w przeciwieństwie do beneficjów prawdziwych) i (zapewne) nie ob-

\footnotetext{
${ }_{119}$ CDB, t. 3, cz. 2, wyd. G. Friedrich, Z. Kristen, Pragae 1962, nr 197.

120 CDB, t. 5, cz. 1, nr 335.

121 CDB, t. 2, nr 329.

122 „Swar men jarlekes ienegen tins af gift, dar ne mach de man an deme gude nen len behalden", Sachsenspiegel II. Lehnrecht, 13 § 3, s. 33.
} 
ciążano ich powinnościami. Nie ulega wątpliwości, że te beneficja były majątkami ziemskimi, nie zaś „udziałami” w dochodach „państwowych”. $\mathrm{Z}$ kolei dobra nadawane iure feudali, z obowiązkiem złożenia przysięgi przez mana, które skłonni jesteśmy identyfikować z lennem dworskim, były zapewne obciążone takimi czy innymi powinnościami.

W związku z powyższym należy zwrócić uwagę na działalność biskupa ołomunieckiego Brunona z Schauenburga (1245-1281), niejednokrotnie już analizowaną w kontekście recepcji (z Niemiec) urządzeń lennych w Czechach/na Morawach oraz związku feudalizmu czesko-morawskiego z kolonizacją. Jak pisze Krzysztof Kowalewski: „w wyniku jego działalności powstała nowa jakość: system lenny, na który składały się lenna nadawane bynajmniej nie okazjonalnie i przypadkowo, lecz zgodnie z góry powziętym planem przebudowy organizacji włości feudalnej"123.

Do elity lenników Brunona należał stolnik Herbord z Fulštejna, który pochodził z Westfalii, rodzinnej krainy biskupa. Otrzymał on w 1255 r. hojne nadanie: 184 łany w 5 wsiach ,iure ministerialium Magdeburgensis ecclesie [- - ]. Idem quoque Herbordus miles, dapifer noster, filios suos [- - ] motu proprii arbitrii sui et eorum dedit et obtulit ministeriales ecclesie nostre, que prius nullos habebat, ut sibi devotione, obsequio, fideque debita ipsi et heredes eorum, necnon et tota posteritas iure ministerialium Magdeburgensis ecclesie perpetuo sint astricti. Quos prefatus dapifer, sicut nobis et capitulo nostro promiserat, ab ecclesia Molebeke, Mindensis diocesis, cuius ante ministeriales fuerant, plene redemit et absolvit et manu mitti procuravit; ipsique per patentes literas abbatisse et conventus eiusdem loci nostre Olomucensi ecclesie liberi sunt transmissi" ${ }^{24}$.Z przytoczonego tekstu niedwuznacznie wynika, że Herbord i jego trzej synowie byli niewolnymi ministeriałami klasztoru benedyktynek w Möllenbeck. Herbord wykupił siebie i synów z niewoli (świadczy o tym zastosowany wokabularz: redempto, absolvo, manu mitto), niewykluczone, że za pieniądze i z protekcji biskupa Brunona. Już jako wyzwoleni (liberi) przenieśli się na Morawy, do dóbr biskupa ołomunieckiego. Wystawca dokumentu powiada, że Herbord z własnej woli oraz z woli swoich synów nadał ich wraz z ich potomnymi wieczyście Kościołowi ołomunieckiemu jako ministeriałów na takim prawie, z jakiego sam korzystał, tj. na prawie ministeriałów arcybiskupa magdeburskiego. Na jego synach ciążył obowiązek gorliwej służby, posłuszeństwa i wierności biskupowi ołomunieckiemu.

Nasuwa się hipoteza, że Herbord wraz z synami zostali niewolnymi ministeriałami biskupa Brunona; biskup podaje, że dotychczas ministe-

${ }^{123}$ K. Kowalewski, op. cit., s. 12.

${ }^{124}$ CDB, t. 5, cz. 1, nr 56. 
riałów nie miał. Co prawda nie mówi się expressis verbis o niewolnej kondycji Herborda i jego synów, ale zapewne było to zrozumiałe samo przez się. Wszak o niewoli Herborda jako ministeriała w Möllenbeck dowiadujemy się tylko dlatego, że jego przenosiny na Morawy były uzależnione od uzyskania przezeń wyzwolenia ${ }^{125}$. $z$ kolei przyznanie Herbordowi niewolnej kondycji na Morawach implikowało zabranie przezeń synów z Möllenbeck, ponieważ według Zwierciadła saskiego po śmierci niewolnego („egen”) do pana należą jego dziedzictwo oraz jego dzieci ${ }^{126}$. W Zwierciadle saskim powiada się także, że jeśli ktoś przed sądem oddaje się w niewolę i sprzeciwi się temu jego dziedzic, powoduje to powrót do stanu wolności ${ }^{127}$. Oddanie synów w niewolę biskupowi Brunonowi (po ich wyzwoleniu z niewoli w Möllenbeck) zabezpieczało pozycję Herborda u nowego pana. Trzeba też zwrócić uwagę na przepis prawa ministeriałów magdeburskich, że dzieci otrzymują prawa rodziców ${ }^{128}$. 0 niewolnej kondycji synów Herborda świadczy pośrednio informacja o ich wieczystej służbie wraz z potomnymi dla biskupa ołomunieckiego. Zatem nieprzypadkowo $\mathrm{w}$ dokumencie został położony nacisk na status synów Herborda, a nie jego samego.

Odnośnie do uposażenia Herborda trafniej byłoby stosować określenia: lenno dworskie, prawo dworskie niż lenno i prawo lenne, jego samego zaś kwalifikować jako ministeriała (Dienstmanna) niż lennika; zresztą wystawca dyplomu stosuje wobec synów Herborda określenie „ministeriales ecclesiae nostrae". Zgodnie ze Zwierciadłem saskim lenno ministeriała nie było prawdziwym lennem (,nen recht len”) ${ }^{129}$. Przyjmując lenno, ministeriał nie składał hołdu na znak podporządkowania się panu, ponieważ już był egen. Jest charakterystyczne, że Herbord najpierw służył Brunonowi (między innymi pomagał mu w trakcie konfliktu z księciem Władysławem Opolskim) ${ }^{130}$, a dopiero potem otrzymał uposażenie.

${ }^{125}$ Zwierciadło saskie zawiera rygorystyczne postanowienia dotyczące statusu osób przenoszących się od jednego pana do drugiego - Sachsenspiegel I. Landrecht, wyd. K. A. Eckhardt, Aalen 1973, III 32, s. 213-214.

${ }^{126}$ „Behalt ene aver de herre wante an sinen dot, he nimt sin erve na sime dode, unde sine kindere, of se na eme horet, de he na der gave gewan", ibidem, III 32 § 8, s. 214 .

${ }^{127}$ „Swe sek vor gerichte to egene gift, sin erve mach it wol weder spreken mit rechte unde brengen ene weder an sin vri", ibidem, III 32 § 7, s. 214.

${ }^{128}$ „Afft jennich dinstman wyf nymmet, dy dinstwyf ys, id sy to Magdeborch eder to Alslleue edder to Engeres edder to Beuera edder to Berga: dy kindere volgen dem vadere vnd behalden doch in beyden haluen ere recht", Codex iuris Bohemici, t. 1, wyd. H. Jireček, Pragae 1867, nr 42 § 12, s. 125.

129 Sachsenspiegel II. Lehnrecht, 63 § 1, s. 81-82. Por.J. Keupp, op. cit., s. 356.

${ }^{130} \mathrm{~W}$ związku z zaangażowaniem Herborda po stronie biskupa Brunona czytamy w dokumencie: „contra predictum nobilem exponere non expavit”, CDB, t. 5, cz. 1, nr 56. 
W dokumencie dla Herborda powiada się o nadaniu ziemi na prawie ministeriałów Kościoła magdeburskiego. W literaturze zwrócono uwagę na to, że warunki, na jakich Bruno nadawał feuda, odbiegały od norm tego prawa ${ }^{131}$. Miloslav Sovadina zauważa, że co prawda relacje między biskupem Brunonem i jego lennikami mogły być regulowane według prawa ministeriałów arcybiskupstwa magdeburskiego, jednak w tekstach dokumentów nie ma o tym mowy. W sumie dochodzi do wniosku, że Bruno nadawał prawdziwe lenna na saskim prawie lennym, dostosowując normy tego prawa do swoich potrzeb. Wszyscy lennicy byli równi, jeżeli zaś zdarzali się ministeriałowie, to jedynie sporadycznie $^{132}$. Można w związku z tym postawić następującą hipotezę: w dokumentach nie ma mowy o tym, że stosunki między biskupem Brunonem i lennikami miały być regulowane według norm prawa arcybiskupów magdeburskich, ponieważ one tak właśnie były regulowane. Nie sposób zgodzić się z poglądem, że Bruno odwoływał się do saskiego prawa lennego, dostosowując jego poszczególne normy; taki zabieg nie był oczywisty po skodyfikowaniu tego prawa w Zwierciadle saskim ${ }^{133}$.

Co zatem oznaczała informacja o nadaniach na prawie ministeriałów magdeburskich? Pewne światło na tę kwestię rzuca postanowienie zawarte $\mathrm{w}$ dyplomie wystawionym przez Brunona w $1251 \mathrm{r}$. dla niejakiego Bertolda („Bertholdo, famulo”), w którym czytamy: „ius vasallorum ecclesie Magdeburgensis habeas in omnibus indistinctum, quod omnibus infeodatis a nobis concedimus"134. Taki zapis spotykamy w wielu dokumentach lennych biskupa Brunona wystawionych później. W przywołanym fragmencie zawarta jest obietnica zastosowania wobec Bertolda takiego samego zespołu norm z prawa ministeriałów magdeburskich, jak wobec pozostałych ministeriałów biskupich, natomiast nie ma mowy o tym, że będzie stosowane prawo ministeriałów magdeburskich w całości. W Zwierciadle saskim powiada się zresztą, że u każdego biskupa czy opata jest inne prawo dworskie ${ }^{135}$. Wydaje się, że biskupowi Brunonowi zależało na odwołaniu się do powszechnie uznanego prawa dworskiego,

${ }^{131}$ Zestawienie literatury: V. Knoll, Jus vassallorum vel ministerialium ecclesiae Magdeburgensis. Poznámka k otázce původu olomouckého lenního práva, „Právněhistorické studie” 37, 2005, s. 18. Autorowi składam serdeczne podziękowanie za przesłanie tej pracy.

${ }_{132}$ M. Sovadina, Lenní listiny biskupa Bruna, „Sborník archivních prací” 24, 1974, 2, s. 442, 456-459.

${ }^{133}$ Nie podważa tej konkluzji nawet okoliczność, że Zwierciadło saskie oddaje stan idealny prawa lennego, jak twierdzi ostatnio Heiner Lück, Woher kommt das Lehnrecht des Sachsenspiegels? Überlegungen zu Genesis, Charakter und Struktur, w: Ausbildung und Verbreitung des Lehnswesens, s. 253.

${ }_{134}$ CDB, t. 4, cz. 1, wyd. J. Šebánek, S. Dušková, Pragae 1962, nr 219.

135 Sachsenspiegel I. Landrecht, III 42 § 2, s. 223; Sachsenspiegel II. Lehnrecht, 63 § 2, s. 82. 
które mógłby przystosować do swoich potrzeb ${ }^{136}$. Nie jest wykluczone, że taką decyzję podjął po próbie osadzania w biskupstwie rycerzy wolnych. Oto w 1249 r. Bruno nadał „Gallo de Lewenberch, viro nobili et strennuo morumque honestate preclaro" dwie wsie „iure pheodali”"137. Bez ryzyka pomyłki można przyjąć, że to nadanie było na prawie lennym, a nie na dworskim. Być może Bruno zastosował tutaj normy saskiego prawa lennego; jednak miał niewielkie możliwości dostosowania norm tego prawa do swoich potrzeb. Z prawem dworskim było zupełnie inaczej.

Wydaje się, że zagadnienie recepcji instytucji ministerialitetu w Czechach nie zostało w literaturze odpowiednio wyeksponowane. K. Kowalewski pisze co prawda, że przyjęcie wzorca ministerialitetu magdeburskiego zasługuje na „szczególną uwagę” oraz że zagadnienie „wpływu niemieckiego ministerialitetu na rozwój ustroju lennego w Czechach [--] czeka jeszcze na wyczerpujące opracowanie" ${ }^{138}$, jednak sam zajmuje się „systemem lennym”. Marcin R. Pauk z kolei, badając otoczenie rycerskie czeskich możnych w XIII w., koncentruje się na zależnościach klientalnej lub lennej, pomijając kwestię ministerialitetu ${ }^{139}$. Wytłumaczeniem takiego podejścia badaczy do instytucji ministerialitetu może być następująca wypowiedź K. Kowalewskiego: „Zestawiając niemiecki ministerialitet z czeskimi systemami lennymi trzeba mieć na uwadze zasadniczą odmienność procesów twórczych tych instytucji, tak odnoszącą się do chronologii, jak i bazy społecznej"140. Autorowi chodzi zapewne o to, że w XIII w. ministerialitet był już w zaniku oraz że ministeriałowie weszli w skład niższej szlachty. Taki pogląd wyraził ostatnio także Vilém Knoll: „Przeważająca większość członków świty i lenników Brunona wywodziła się z ministerialitetu, zatem pierwotnie była pochodzenia niewolnego. Jednakże w XIII w. ministerialitet rozpadał się już na inne grupy społeczne" 141 .

136 Por. też V. Knoll, op. cit., s. 18.

137 CDB, t. 4, cz. 1, nr 161. Por. M. Sovadina, op. cit., s. 441-442.

${ }^{138}$ K. Kowalewski, Rycerze, włodycy, panosze, s. 12 n.; idem, Powstanie systemów lennych na ziemiach czeskich $w$ średniowieczu, RDSG 58, 1998, s. 131.

${ }^{139}$ M. R. Pauk, Fama, gloria, curia ac ingens familia. Stużba i klientela rycerska $w$ otoczeniu możnowładztwa czeskiego (XIII-początek XIV wieku), w: Dom, majątek, klient, sługa. Manifestacja pozycji elit w przestrzeni materialnej i społecznej (XIII-XIV wiek), red. idem, M. Saczyńska, Warszawa 2010, s. 27-62; idem, Der böhmische Adel im 13. Jahrhundert: Zwischen Herrschaftsbildung und Gemeinschaftsgefühl, w: Böhmen und seine Nachbarn in der Přemyslidenzeit, red. I. Hlaváček, A. Patschovsky, Ostfildern 2011, s. 247-287, tutaj s. 275-278.

${ }^{140}$ K. Kowalewski, Powstanie systemów lennych, s. 132, przyp. 26; idem, Rycerze, włodycy, panosze, s. 13, przyp. 29.

141 „Valná většina Brunových družiníků a leníků byla ministerálního, tedy původně nesvobodného původu. Ve 13. století se však již ministerialita rozpadala do ostatních sociálních skupin", V. Knoll, op. cit., s. 22. 
Wyżej zwracaliśmy uwagę na przeciwstawianie w końcu XII-XIII w. prawa służebnego i prawa lennego. Jan Keupp proponuje traktować to zjawisko jako przejaw ówczesnych procesów racjonalizacji prawa, a nie jako relikt dawniejszych czasów ${ }^{142}$. W każdym razie jeszcze na początku XIV w. słyszymy o „milites seu vasalli iure Magdeburgensi” biskupa ołomunieckiego ${ }^{143}$.

K. Kowalewski za M. Sovadiną zestawił różnice między przepisami prawa ministeriałów magdeburskich i ministeriałami biskupa Brunona. Na czoło wysuwają się normy dotyczące dziedziczenia lenna przez synów, obowiązku dokupywania ziemi przez ministeriałów (bona empticia), obowiązku uiszczania czynszu rekognicyjnego ${ }^{144}$.

Zwraca uwagę zawężenie kręgu spadkobierców do synów, podczas gdy w magdeburskim prawie służebnym dziedziczyli „sonen, dochter, bruder, suster vader und muder" ${ }^{145}$. Norma zastosowana przez biskupa Brunona jest charakterystyczna dla prawa lennego, w którym dziedziczył syn (synowie), chociaż bywały wyjątki na rzecz córek czy krewnych bocznych. Być może Brunonowi chodziło o podkreślenie różnicy w stosunku do hereditates rycerzy czeskich, które według statutów księcia Konrada Ottona z 1189 r. mogły dziedziczyć także córki ${ }^{146}$.

Uwidoczniony w połowie nadań od biskupa Brunona obowiązek dokupienia przez ministeriałów ziemi w wymiarze $1 / 3-1 / 2$ wartości lenna służebnego ma z kolei aspekt kolonizacyjny ${ }^{147}$. Status tych bona empticia (wchodzących w skład lenna) był o tyle odmienny, że dziedziczyły je córki ministeriała, a ponadto nie były one obciążone czynszem rekognicyjnym, który mieli płacić swojemu panu ministeriałowie biskupa Brunona. Informacje o czynszu rekognicyjnym wskazują, że ministeriałowie ci nie posiadali prawdziwych lenn ${ }^{148}$.

${ }^{142}$ J. Keupp, op. cit., s. 360.

${ }^{143}$ Codex diplomaticus et epistolaris Moraviae, t. 6, wyd. P. Chlumecky, Brünn 1854, nr 9, 1307 r.

${ }^{144}$ K. Kowalewski, Powstanie systemów lennych, s. 131; idem, Rycerze, włodycy, panosze, s. 12.

${ }^{145}$ Codex iuris Bohemici, t. 1 , nr $42 \S 4$, s. 125.

146 Pozostawiamy na uboczu sporną w literaturze kwestię dziedziczenia majątków ziemskich rycerskich przez córki na podstawie postanowień statutu Konrada Ottona. Chodzi nam o normę prawną, a nie o praktyczne stosowanie prawa, które może od normy odbiegać. Zob. J. Žemlička, Počátky Čech královských, s. 362-364; idem, 0 „svobodné soukromnosti” pozemkového vlastnictví, „Český časopis historický” 107, 2009, 2, s. 282 nn.; idem, Přemysl Otakar II., s. 69 nn.; L. Jan, Hereditates a soudy statut Konráda Oty, w: Ad iustitiam et bonum commune. Proměny zemského práva v českých zemích ve středověku a raném novověku, red. L. Jan, D. Janiš, Brno 2010, s. 10-22.

147 Por. M. Sovadina, op. cit., s. 459.

${ }^{148}$ Por. wyżej. 
Z kolei zwróćmy uwagę na dokumentację dotyczącą majątków możnowładców świeckich. Od schyłku XII i w XIII w. budowali oni swoje władztwa, opierając się na zamkach, zależnych rycerzach i fundacjach klasztornych ${ }^{149}$. W dyplomie wystawionym przez komesa Hroznatę w 1197 r. w związku z fundacja klasztoru premonstratensów w Tepli czytamy: „,Milites mei, qui a me predia mea tenent"150. Owi rycerze mieli otrzymać od 1 do 5 grzywien odszkodowania za posiadane majątki (wielkości od jednego aratrum do jednej wsi), po czym każdy z nich „cui voluerit serviat”. W tych rycerzach można by dopatrywać się ministeriałów ${ }^{151}$. Z kolei w testamencie Voka z Rožmberka z $1262 \mathrm{r}$. wspomina się o pieniądzach do rozdzielenia ,inter orphanos meos et orphanos fratris mei, servos illos scilicet, quorum patres a me nulla feoda tenuerunt” ${ }^{152}$. Owych „patres" można by chyba zakwalifikować jako ministeriałów $w^{153}$.

W drugiej połowie XIII w. lenna drobnych rycerzy pojawiły się w majątkach królewskich. Skąpa dokumentacja utrudnia badanie tego zagadnienia ${ }^{154}$. Natomiast w świetle materiału zebranego przez K. Kowalewskiego odnośnie do organizacji domeny monarszej w Królestwie Czech w XIV-XV w. można dojść do wniosku, że drobni lennicy byli wówczas traktowani jako quasi-ministeriałowie. Ich majątek ziemski mieścił się w granicach od połowy łana do ponad 1 wsi, najczęściej było to kilka łanów $^{155}$, czyli mniej więcej tyle, ile posiadali milites komesa Hroznaty

${ }^{149}$ M. R. Pauk, Fama, gloria, curia; idem, Społeczne uwarunkowania powstania zamków możnowładczych $w$ Czechach (XIII-pocz. XIV wieku), w: Zamek i dwór w średniowieczu, red. J. Wiesiołowski, Poznań 2001, s. 11-17; idem, Der böhmische Adel, s. 262 nn.; w sprawie zamków por. ostatnio W. Iwańczak, Zamki królewskie i arystokratyczne w Czechach jako miejsce tworzenia, recepcji i przekazywania wzorów kultury, w: Kultura średniowiecznego Ślaska i Czech. Zamek, red. K. Wachowski, Wrocław 1996, s. 13-20; R. Šimůnek, Hrad jako symbol v myšlení české středověké šlechty, „Český časopis historický” 108, 2010, 2, s. 185-219. M.R. Pauk podkreśla, że nobiles w XI-XII w. opierali swoje stanowisko przede wszystkim na służbie księciu, w XIII w. - na wielkiej własności (alodialnej) z nadań władców oraz zwłaszcza na własnej działalności kolonizacyjnej na obszarach przygranicznych, a także na kulturze rycerskiej (jakkolwiek urzędy i beneficja nadal pozostały ważnymi źródłami dochodu oraz źródłem prestiżu nobilów). Jednak w połowie XIII w. sprawowanie urzędu nie było warunkiem niezbędnym do osiągnięcia najwyższych pozycji. W związku z tym nie było kontynuacji między społeczną elitą XI-XII w. a elitą końca XII-XIII w., M.R. Pauk, Der böhmische Adel, s. 254-257, 260, 264-265.

150 CDB, t. 1, nr 357.

${ }^{151}$ Por. J. Keupp, op. cit., s. 356 n.; por. L. Jan, Václav II., s. 223: „ministeriály či klienty”. J. Žemlička (Počátky Čech královských, s. 360) pisze, że chodzi tutaj o osoby, które „se stávali jakýmisi [- ] «leníky»”. Por. K. Andermann, op. cit., s. 329: ministeriałowie bez lenna mogą u jednych panów odejść, u innych służą tak jak ci, którzy lenno posiadają.

${ }^{152}$ CDB, t. 5, cz. 1 , nr 335.

${ }^{153}$ L. Jan, Václav II., s. 224, ma tutaj na myśli klientelę.

154 Zob. ostatnio J. Žemlička, Přemysl Otakar II., s. $218 \mathrm{nn}$.

${ }^{155}$ K. Kowalewski, Rycerze, włodycy, panosze, s. 97; idem, Powstanie systemu lennego 
około 1200 r. W późnym średniowieczu funkcjonowało pojęcie prawdziwego lenna (feudum verum, prave manstvo) ${ }^{156}$. Zdaniem K. Kowalewskiego to określenie służyło do odróżniania lenników od klienteli wynagradzanej w pieniądzu ${ }^{157}$. Wydaje się jednak, że pojęcie prawdziwe lenno było używane w rozumieniu takim, jak w Zwierciadle saskim, tj. jako przeciwieństwo houeleen. Wskazuje na to pośrednio zapis z dyplomu z 1345 r.: „feudum verum secundum ius theutonicum" 158 ; owo ius theutonicum może oznaczać tylko saskie prawo lenne ${ }^{159}$. K. Kowalewski zwraca uwagę na zróżnicowanie prawa obowiązującego drobnych lenników w poszczególnych wielkich majątkach ${ }^{160}$ - jest to cecha prawa dworskiego. W rozbudowanej hierarchii stanowych kwalifikatorów lenna zwraca uwagę określenie lenno służebne ${ }^{161}$. Służebnicy składali przysięgę, nie było mowy o hołdzie. Ciekawa jest opinia Prokopa, piętnastowiecznego notariusza z Nowego Miasta Praskiego, o panoszach (w skład tej grupy wchodzili służebnicy): panosza to tytuł „służebny” i „niewolny” (,jméno služebné jest a nesvobodné") ${ }^{162}$. Usilne starania owych służebnych rycerzy o to, aby znaleźć się w obrębie stanu włodyczego/rycerskiego, także są świadectwem niskiego statusu członków owej grupy ${ }^{163}$.

W literaturze znany jest przypadek Hojera z Landštejna, który przyjął pewne „bona militaria [- - ] in pheudum” od Jindřicha z Lipy i w związku z tym Karol IV wystawił w 1360 r. dokument mówiący o tym, że przyjęcie (i zrzeczenie się) owego lenna nie będzie miało konsekwencji dotyczących szlachectwa Hojera (nobilitatis status, gradus, honor et ordo). Zdaniem Františka Kavki lenno służebne było w tym czasie nie do pogodzenia ze statusem przynależnym wyższej szlachcie ${ }^{164}$. Z kolei według M. R. Pauka ten przypadek świadczy o tym, że „pełna nobilitas nie mogła iść w parze

w domenie monarszej ostatnich Przemyślidów i pierwszych Luksemburgów, RDSG 56-57, 1996/1997, s. 5-27.

${ }^{156}$ Zob. przykładowe wzmianki w: K. Kowalewski, Rycerze, włodycy, panosze, s. 63, przyp. 152; zob. też F. Kavka, Západoevropský lenní institut jako nástroj vnitřní královské politiky za posledních Přemyslovců a za Jana Lucemburského, „Český časopis historický” 88, 1990, 3, s. 225-251, tutaj s. 237: feudum liberum = rechtes lehen.

${ }^{157}$ K. Kowalewski, Rycerze, włodycy, panosze, s. 62 n.i przyp. 151.

${ }^{158}$ Regesta diplomatica nec non epistolaria Bohemiae et Moravia (dalej: RBM), cz. 4, wyd. J. Emler, Pragae 1892, nr 1602.

${ }^{159}$ Przesłanką naszego wnioskowania jest połączenie terminu „feudum verum” (znanego ze Zwierciadła saskiego - „recht len”) z terminem „ius theutonicum”, które może oznaczać tutaj tylko saskie prawo (lenne), bo jakie inne mogłoby wchodzić w grę?

${ }^{160}$ K. Kowalewski, Powstanie systemów lennych, s. 136 n.

${ }^{161}$ Idem, Rycerze, włodycy, panosze, s. 65.

162 Ibidem, s. 77 n. i przyp. 209.

${ }^{163}$ Ibidem, s. 76, 85.

${ }^{164}$ F. Kavka, op. cit., s. 229-230. 
z pozostawaniem w relacji zależności od kogokolwiek z wyjątkiem króla"165. Pojawia się pytanie, co oznacza określenie lenno służebne w ujęciu F. Kavki. Można się domyślać, że pod tym określeniem kryje się lenno nadane przez możnego pana, a nie przez króla. Autor ten przywołuje przypadek (wspomniany wyżej) nadania przez biskupa ołomunieckiego Brunona Gallowi z Lemberku, określonemu jako „nobilis vir”, dwóch wsi „titulo feodi” i wyraża przypuszczenie, że być może w tym przypadku powinności służebne miały drugorzędne znaczenie, co pozwalało pogodzić tę relację ze statusem szlachcica o wyższej pozycji. Autor dodaje, że wydzielanie się wyższej szlachty w osobny stan nie było jeszcze w XIII/ XIV w. powszechne ${ }^{166}$. Otóż zwróciliśmy już uwagę na to, że w dokumencie Brunona dla Galla nie ma słowa o prawie ministeriałów arcybiskupstwa magdeburskiego. Zatem nasuwa się przypuszczenie, że to nadanie było na warunkach prawdziwego lenna, a nie lenna dworskiego. I teraz powstaje pytanie o warunki nadania dla Hojera z Landštejna - czy było to prawdziwe lenno, czy nieprawdziwe? Innymi słowy, nie każde lenno od możnego pana należy traktować jako lenno służebne.

Jednak prawdziwe lenno (feudum nobile, feudum honorabile, feudum liberum) pojawia się w Królestwie Czech przede wszystkim w związku z relacjami między królem a magnatami, zwłaszcza od okresu panowania Jana Luksemburskiego. F. Kavka jest zdania, że ostatni Przemyślidzi preferowali tzw. wysługi, ale z klauzulą dotyczącą powinności beneficjenta, a zatem $\mathrm{z}$ formułą quasi-lenną. $\mathrm{Z}$ kolei L. Jan, trzymając się swojego poglądu o beneficjach (beneficium-suppa - por. wyżej), uważa, że w końcu XIII w. mogły być one nadawane z zastosowaniem rytuału podania ręki i złożeniem przysięgi wierności. Ta przysięga wywodziła się być może z prawa ziemskiego: „Niemniej przeto pojawia się w końcu XIII w. także na praskim dworze formularz, prawdopodobnie należy to uważać już za jakieś przejście do symbolicznej przysięgi lennej"167. Wszystko to przypomina teorię Wilhelma Weizsäckera o czeskich beneficjach jako „Keimund Vorform" lenna (zob. wyżej). W każdym bądź razie w dokumentach wystawianych przez kancelarię Wacława II w związku z nadaniami zamków etc. lub w formularzach spotykamy formuły przysiąg typu: „omni tempore fideliter et devote servire, velut alter terrigena suus”, „, servire et obedire in omnibus, que iusserit”, „ut alter aliquis fidelis baro de regno Boemie sibi servire et parere tenetur et debetur". Takie przysięgi,

${ }^{165}$ M. R. Pauk, Fama, gloria, curia, s. 60.

166 F. Kavka, op. cit., s. 231-232.

167 „Přesto se v závěru 13. století objevuje i na pražském dvoře forma, již je třeba pravděpodobně považovat za jistý přechod k symbolické lenní přísaze", L. Jan, Václav II., s. 225. 
przypuszcza L. Jan, mogły być składane przez czeskich możnych już za panowania Przemysła Otokara II. Cytowany autor rozpatruje dwie możliwe interpretacje tych przysiąg: ,albo chodzi o sytuację będącą następstwem [--] zasady, że [baronowie - M. D.] dzierżą wolną ziemię [- - ], która pierwotnie nie była ich, albo będącą następstwem faktu, że czescy baronowie są już od długiego czasu faktycznymi lennikami czeskiego władcy"168. Opowiada się raczej za drugą interpretacją. To stanowisko nie przekonuje, wiadomo bowiem skądinąd, że (prawdziwe, tj. nie dworskie) lenno - mimo całej znajomości tej instytucji w Czechach/na Morawach w XIII w. - przyjmowało się powoli, i to raczej w związku z rycerzami pochodzenia obcego. Przełom w tym zakresie nastąpił dopiero w pierwszej połowie XIV w. ${ }^{169}$ Natomiast zasługuje na rozważenie w przyszłości interpretacja pierwsza, łącząca przysięgę wierności i służby „baronów” z faktem posiadania ziemi na pełną własność z nadania władcy. Pojawienie się takich przysiąg w Czechach/na Morawach trzeba by traktować jako wskaźnik ważnych zmian społecznych (konsolidacja wyższej szlachty) oraz politycznych (formalizacja relacji: król - „baronowie”).

Z 1284 r. pochodzą dwa dokumenty istotne dla dyskutowanej problematyki; w każdym z nich odrębna grupa szlachty czeskiej (barones) oświadcza Wacławowi II: „promittimus [- - ] fidelitatem et homagium [--] sibique parebimus et seruiemus in omnibus, sicut regi et nostro domino naturali" ${ }^{170}$. Jak interpretować termin homagium, zaczerpnięty oczywiście ze stosunków lennych? Nic nie wskazuje na to, że w 1284 r. czescy barones składali swojemu władcy hołd lenny. Skądinąd wiadomo, że homagia stosowano także poza prawem lennym ${ }^{171}$. Sformułowanie „promittimus [- - ] homagium” można rozumieć jako synonim formuły „promittimus [- ] servitium et obsequium”; w stosunkach lennych złożenie hołdu oznaczało zobowiązanie się do służby i posłuszeństwa. Zwraca uwagę informacja, że baronowie deklarują pełnienie służby na żądanie Wacława II jako króla i „pana naturalnego” - takie postawienie sprawy nie ma nic wspólnego z prawem lennym.

168 „bud'jde o poměr odvozený [- - ] z toho principu, že [baroni] drží svobodnou půdu [- ], která původně nebyla jejich, nebo ze skutečnosti, že čeští baroni jsou již po dlouhou dobu faktickými leníky českého vládce”, ibidem, s. 233.

${ }^{169}$ F. Kavka, op. cit., s. 232.

170 RBM, cz. 2, wyd. J. Emler, Pragae 1882, nr 1316-1317.

${ }^{171}$ F. L. Ganshof, Was ist das Lehnswesen?, Darmstadt 1975, s. 76. Konsekwentnie lenną interpretację terminu homagium w odniesieniu do Czech proponuje Jaroslav Čechura, Člověčenství (1993), w: Sedláci si dělají, co chtějí. Sborník vybraných prací profesora Jaroslava Čechury, red. V. Boháčová, V. Kucrová, Praha 2012, s. 217-235, tutaj s. 222-224. 
Warto skonfrontować informacje z tych dokumentów z treścią dyplomu z 1289 r., jaki wystawił książę bytomski Kazimierz w związku z objęciem swojego księstwa jako lenna (feudum oblatum) z rąk Wacława II:

a uobis domino meo in feudum et iure feudi predictum ducatum [--] recepi $[--]$ uobisque $[--]$ homagium feci et facio, et uobis fidelitatem, deuotionem et obedientiam perpetuas $[--]$ promisi $[--]$ corporali interposito iuramento $[--]$. Obligando $[--]$ me $[--]$ uobis $[--]$ quod uos iusseritis [- - ] iuuabo [--] fideliter toto posse tanquam uester uassallus quilibet siue baro regni uestri, nec non ad omnia alia et singula [- - ] que iura feuda exigunt et requirunt, et etiam ad illa, que quisque fidelis vasallus suo uero domino facere potest in omnibus atque debet ${ }^{172}$.

Nie mamy wątpliwości co do faktu złożenia przez księcia Kazimierza hołdu lennego i przysięgi lennej. Jeżeli chodzi o obligacje Kazimierza, to wyraźnie rozpadają się one na dwie grupy. Po pierwsze, książę miał wspierać Wacława we wszystkich sprawach na jego żądanie, tak jak wasal królewski albo baron królestwa; po drugie, miał pomagać Wacławowi we wszystkim, czego wymaga prawo lenne, tak jak wierny wasal może i powinien czynić. $Z$ takiego podziału powinności wynika, że zobowiązania grupy pierwszej nie miały charakteru lennego, najwyżej jakiś wasalski, wynikający z prawa ziemskiego. Tylko w prawie ziemskim mogła być ugruntowana służba baronów na żądanie władcy. Książę Kazimierz stawał się w ten sposób jednym z baronów królestwa. Jak widać, fakt, że stał się lennikiem Wacława II, nie był wystarczającą podstawą, aby wejść do grona baronów królestwa, ponieważ prawo lenne nie było czynnikiem integrującym baronów. Z kolei zobowiązania w grupie drugiej miały naturę lenną - Kazimierz wspierał Wacława we wszystkim, w czym mógł i powinien był wspierać jako wierny wasal.

Wykorzystanie przez władców czeskich z dynastii Luksemburgów przede wszystkim Jana oraz Karola IV - lenna jako narzędzia wewnętrznej polityki stanowi wielką różnicę w stosunku do czternastowiecznej Polski. Obce pochodzenie dynastii, a także obce, niemieckie pochodzenie wielu lenników grały bez wątpienia istotną rolę w recepcji prawa lennego w Królestwie Czech. Problematyka ta została opracowana w nowszej literaturze przez F. Kavkę $e^{173}$; nie ma potrzeby powtarzania jego szczegółowych ustaleń. Wystarczy tylko wspomnieć, że obiektem nadań lennych były przede wszystkim zamki, bądź królewskie, często jako zastaw, bądź

172 RBM, cz. 2, nr 1466.

${ }^{173}$ F. Kavka, op. cit., s. 229 nn. 
baronów, nadawane im jako feudum oblatum; te ostatnie nadania przeważały. Wasalami Korony w czasach panowania Jana stali się magnaci z 18 rodów, z tego z 10 czeskich, w tym z 7 czołowych; 27\% zamków było pod bezpośrednią względnie pośrednią kontrolą króla. Karol IV kontynuował lenną politykę swego ojca, ale na mniejsza skalę.

Ogólnie rzecz biorąc, liczba prawdziwych lenn nie była w Czechach/na Morawach imponująca. W literaturze przedmiotu przeważa,jak się wydaje, uzasadniony pogląd, że podstawowymi czynnikami strukturującymi tamtejszą szlachtę były urzędy ziemskie i prawo ziemskie ${ }^{174}$. Ostatnio Wojciech Iwańczak wyraził opinię, że Królestwo Czeskie, ,kraj, który pod pewnymi względami najsilniej [w Europie Środkowo-Wschodniej - M.D.] poddany był wpływom zachodnim, [--] zwłaszcza za panowania Luksemburgów, stworzył bogatą kulturę rycerską, która w znacznym stopniu stanowiła odbicie interesujących trendów zachodnioeuropejskich, ale posiadała także pewne elementy oryginalne"175. Zapewne kultura współzawodnictwa i rywalizacji została w środowisku szlachty Królestwa Czech przyjęta szerzej niż w Polsce, jednak nie na tyle, żeby uruchomić mechanizm pełnej feudalizacji tej grupy społecznej.

\section{VI}

Zagadnienie feudalizmu na Węgrzech jest badane już od dobrych stu lat ${ }^{176}$. Pierwsza kwestia, jaka nasuwa się w związku z tymi badaniami, to status prawny majątków tamtejszej szlachty. Gyula Kristó wyraża pogląd, że już we wcześniejszym średniowieczu Węgry miały charakter „państwa feudalnego", tzn. gospodarka była oparta na prywatnej („feudalnej”/,senioralnej”) własności króla i możnych ${ }^{177}$. Z kolei Pál Engel uważa, że te majątki nobilów były traktowane jak alodium (haereditas). Owszem, król Andrzej II miał w planach wprowadzenie feudalnej służby

${ }^{174}$ W. Iwańczak, Tropem rycerskiej przygody. Wzorzec rycerski w piśmiennictwie czeskim XIV wieku, Warszawa 1985, s. 27; K. Kowalewski, Rycerze, włodycy, panosze, s. 73.

175 W. Iwańczak, Rola i znaczenie dwóch kręgów cywilizacyjnych, s. 102-103. Ostatnio zob. D. Dvořáčková-Malá, J. Zelenka, Curia ducis, curia regis. Panovnický dvưr za vlády Přemyslovců, Praha 2011, rozdz. 5; D. Dvořáčková-Malá, Královský dvůr Vaclava II., České Budějovice 2011, rozdz. 4.

${ }^{176}$ Zob. rekapitulację literatury przedmiotu: J. M. Bak, Feudalism in Hungary?, w: Feudalism. New Landscapes of Debate, s. 207-209.

177 G. Kristó, Histoire de la Hongrie Médiévale, t. 1: Le temps des Arpads, Rennes 2000, s. 89-92. Autor wyróżnia dwie grupy nobilów: przychylnych dla feudalizmu i opozycyjnych wobec niego. Przy końcu XI w. była już grupa arystokracji feudalnej, złożona z cudzoziemców i części panów węgierskich, stawiająca na służbę jako podstawę pozycji społecznej; grupa arystokracji przywiązanej do tradycji widziała źródło powodzenia życiowego w przynależności do czołowych rodów (ibidem, s. 96-97). 
rycerskiej (podstawą tego planu miały być królewskie nadania ziemi), ale te zamiary nie zostały zrealizowane. Nadania dla szlachty były wynagrodzeniem za zasługi, a nie za przyszłe służby ${ }^{178}$. Ostatnio także J. M. Bak wyraził pogląd, że dobra szlachty można uważać za własność alodialną ${ }^{179}$. Cytowany uczony podkreśla, że nadania królewskie były wynagrodzeniem za służby pełnione przez szlachcica w przeszłości; władca rzadko wyszczególniał warunki takiej donacji. J. M. Bak konkluduje: „Jeżeli nie istnieje lenno, to nie może istnieć wasal" ${ }^{180}$.

Jednak w świetle spisu węgierskiego prawa zwyczajowego autorstwa Stefana Werbőczyego, znanego pod skróconym tytułem Tripartitum (1514), status prawny majątków szlacheckich nie jest łatwy do precyzyjnego określenia. Przede wszystkim znajduje się tam zapis, że do królów węgierskich należy „omnis nobilitationis et exconsequenti possessionariae collationis qua nobiles decorantur [- - ] facultas" 181 . Z kolei o szlachectwie powiada się, że „vera nobilitas usu disciplinaque militari ac caeteris animi corporisque dotibus et virtutibus acquiritur" 182 . Natomiast o majątkach szlachty jest informacja, że szlachcice „eorum iura possessionaria ex donationibus [- - ] regum Hungariae habent atque possident”, po czym dodaje się, że „Pura donatio est iurium possessionariorum in iurisdictionem sacrae regni coronę legitimę redactorum perennalis per principem cuipiam ob servitia vel praeclaras virtutes facta collatio"183. Szlachcice nie uiszczają z nadanych im majątków żadnych podatków ani innych świadczeń, są zwolnieni od wszelkiej „conditionaria servitute", natomiast są zobowiązani do służby wojskowej dla obrony królestwa ${ }^{184}$. Zatem widać, że zwornikiem tego systemu jest (uprzednia) służba wojskowa ${ }^{185}$. Ona właśnie jest podstawą nadania ma-

178 P. Engel, The Realm of St Stephen. A History of Medieval Hungary 895-1526, LondonNew York 2005, s. 80, 91, 93: „This short-lived feudalism was not, however, to survive”.

179 "the land of nobiles was in theory not burdened with any duty. Every nobleman had the duty to follow the king's flag in battle and had the right and duty to appear at noble assemblies [- ] but these flowed from his fidelity to the crown, not from his landholding", J. M. Bak, Feudalism in Hungary?, s. 207.

180 "If there is no fief, there can be no vassal", ibidem, s. 206.

181 The Customary Law of the Renowned Kingdom of Hungary: A Work in Three Parts Rendered by Stephen Werböczy (The „Tripartitum”) - Tripartitum opus iuris consuetudinarii inclyti regni Hungariae per Stephanum de Werbewcz editum, wyd. J. M. Bak i in., Idyllwild, Calif.-Budapest 2005, I.3 § 6 .

182 Ibidem, I. 4.

183 Ibidem, I.13 i § 2.

${ }^{184}$ Ibidem, I.9 § 5. W sprawie ludności służebnej określanej mianem conditionarii zob. P. Engel, op. cit., s. 75.

185 P. Engel (op. cit., s. 83-84) pisze, że podstawą wydzielenia szlachty była ,the allodial nature of its property and the privileges that were attached to it. Their status had nothing to do with chivalry, which was idea that was hardly known". 
jątku, a jego posiadacz z racji owego nadania staje się „prawdziwym szlachcicem" $i$,ab omni rusticitatis iugo eripitur" (zapewne ,iugum rusticitatis” jest synonimem wspomnianej wyżej „servitus conditionaria”) ${ }^{186}$. Według Martyna Rady'ego nie da się w istocie określić rodzaju więzi łączącej szlachcica z królem; można by ją określić jako „przywiązanie”187. Jednak w Tripartitum powiada się, że duchowni z tytułu nadanych im beneficjów kościelnych oraz z tytułu innych dóbr kościelnych są zobowiązani do składania królowi przysięgi wierności (homagium fidelitatis) „instar personarum secularium" ${ }^{188}$. Może zatem termin fidelitas najlepiej definiuje relację między szlachcicem i królem? Inna sprawa, że termin ten oznaczał nie tylko służbę królowi, skoro w Tripartitum pod słowem infidelitas rozumiano wystąpienie przeciw porządkowi publicznemu. Wyszczególniono wiele przypadków takiej niewierności; karą była konfiskata majątku ${ }^{189}$.Zwraca uwagę, że naruszenia porządku publicznego przez nieszlachciców są karane głową sprawcy, a nie konfiskatą nieruchomości, majątki zaś przechodzą na uprawnionych spadkobierców ${ }^{190}$.

Powstaje pytanie, kiedy pojawiła się idea, że majątki szlachty wywodzą się z nadań od królów. W kronice Szymona z Kéza, datowanej na schyłek XIII w., znajduje się wiadomość, że „servientes regibus vel caeteris regni dominis ex ipsis pheuda acquirendo nobilitatem processu temporis sunt adepti" ${ }^{191}$.Z tej informacji wynika, że servientes pozostawali w służbie króla zanim otrzymali lenna. Jakie było ich pierwotne położenie prawne, czy może zbliżone do statusu ministeriałów? ${ }^{192}$ Przyjmuje się, że w XI-XII w.

${ }^{186}$ Por.jednak The Customary Law, I.6: „nobiles etiam absque possessionaria donatione creantur".

187 ,the relationship between king and noble [- - ] might be described simply in terms of «love»", M. Rady, Nobility, Land and Service in Medieval Hungary, New York 2000 , s. 3.

${ }^{188}$ The Customary Law, I.12.Zdaniem wydawców (ibidem, s. 63 przyp. 118) szlachcice w rzeczywistości nie składali takich przysiąg, ponieważ uprzednią służbą dowiedli monarsze swojej wierności.

${ }^{189}$ Ibidem, I.13 § 5 i I.14.

190 Ibidem, I.15.

${ }^{191}$ Cyt. za S. Russocki, Struktury i świadomość. Procesy integracji rycerstwa Europy środkowej schyłku XIII w. i ich odbicie w historiografii epoki, w: Społeczeństwo Polski średniowiecznej.Zbiór studiów, t. 1, red. S. K. Kuczyński, Warszawa 1981, s. 212-213, przyp. 22. Por. P. Engel, op. cit., s. 121.

192 Por. J. Szűcs, op. cit., s. 66: „Teoria kładła nacisk na respektowanie «człowieczeństwa i honoru» [w relacjach między panami a szlachtą - M.D.], w rzeczywistości jednak zależność «odgórna» miała tu bardziej służalczy charakter aniżeli w stosunkach lennych na Zachodzie (dowodzi tego również jeszcze jedno określenie półwasala: serviens)". W świetle postanowień Złotej Bulli króla Andrzeja II z 1222 r. stanowisko społeczne servientes przed wystawieniem tego przywileju należy ocenić jako bardzo niskie. 
do szlachty zaliczano osoby określane jako proceres, principes, pochodzące z arystokratycznych rodów, natomiast w XIII w. termin nobiles objął także licznych królewskich servientes. Jednak dopiero w XIV w. pojawił się pogląd, że szlachcicem jest właściciel ziemski, który posiada majątek dziedziczny z nadania królewskiego ${ }^{193}$. Pogląd ten był zapewne forsowany przez króla Karola Roberta, który nawiązywał do znanych sobie realiów feudalnych w Królestwie Neapolu ${ }^{194}$. W ten sposób eksponowano rzeczowy wymiar relacji między królem i szlachcicem; wymiar personalny tej relacji mieścił się w pojęciu fidelitas. Wszystko to razem składało się na więź quasi feudalną; chyba nie przypadkiem Szymon z Kéza posłużył się terminem pheudum ${ }^{195}$. W każdym razie na pierwszy plan wychodziło szlachectwo ugruntowane w służbie dla króla i w nadaniu ziemi przez króla, a nie w arystokratycznym rodzie. Jednak, $\mathrm{z}$ drugiej strony, redefinicja pojęcia szlachectwa nie została połączona z rzeczywistym wprowadzeniem prawa lennego ${ }^{196}$.

Według M. Rady'ego przed wiekiem XIII termin servientes stosowano nieprecyzyjnie. W każdym razie servientes regis wchodzili w skład familii (domus, aula) króla, łączyła ich z władcą więź bezpośrednia i osobista, oznaczana terminem fidelitas ${ }^{197}$. Powstaje jednak pytanie, czy status wszystkich członków królewskiej familii, po włączeniu servientes do kręgu szlachty, był taki sam. To wydaje się wątpliwe. Zwraca uwagę zapis w Tripartitum: „Per nobiles autem hoc in loco generaliter universos dominos pręlatos, barones caeterosque magnates et alios regni huius proceres intellige qui [--] una eiusdemque libertatis praerogativa semper muniuntur" ${ }^{198}$; implicite jest tutaj mowa o dystansie między tą arystokracją a servientes. Zapewne nie przypadkiem także podkreślono w Tripartitum wolność prawdziwej szlachty od „iugum risticitatis” względnie od „servitia conditionaria”. Dlatego pogląd M. Rady'ego, że servientes z racji ich domniemanej przynależności do królewskiej familii cieszyli się statusem porównywalnym z po-

${ }^{193}$ Np. M. Rady, op. cit., s. 1; P. Engel, op. cit., s. 93 n., 120.

${ }^{194}$ M. Rady,op. cit., s. 60. Autor podkreśla fiskalne cele monarchy.

195 W sprawie feudalnej terminologii na Węgrzech zob. E. Fügedi, Castle and Society in Medieval Hungary (1000-1437), Budapest 1986, s. 61: o terminach leunes, lehen jako określeniach gospodarstw osadników-Niemców; M. Rady, op. cit., s. 142: słowo feudum w kronice Szymona z Kéza; J. M. Bak, Feudalism in Hungary?, s. 203: o różnych znaczeniach słowa feudum.

196 Por. M. Rady, op. cit., s. 78; J. M. Bak, Feudalism in Hungary?, s. 205 n.

197 „The allegiance of the serviens to the king was not, however, dictated by rewards [- ] nor was it discharged by reason of the land he had given. It arouse instead out of the personal bond of fidelity which united man to lord and which was expected of members of the king's domus and familia", M. Rady, op. cit., s. 37; także G. Kristó, op. cit., s. 115-116, 129-130, 131-132, 136-137.

${ }^{198}$ The Customary Law, I.9 § 7. 
zycją poważanych rodzin szlacheckich ${ }^{199}$, nie wydaje się przekonujący. W dekrecie z 1351 r. postanowiono, ,ut universi veri nobiles intra terminos regni nostri constitute [- ] sub una et eadem libertate gratulentur" ${ }^{200}$. Ten zapis nie przesądzał, że wszyscy servientes regis weszli w skład grupy prawdziwej szlachty.

Zdaniem M. Rady'ego od schyłku XIII w. pod określeniem servientes kryli się szlachcice, którzy wstąpili na służbę u wielkich panów jako familiares i otrzymali ziemię na określonych warunkach ${ }^{201}$. Taki szlachcic, w przeciwieństwie do prawdziwego szlachcica (nobilis regni), był określany mianem nobilis iobagio, nobilis exercituans lub nobilis praedialis ${ }^{202}$. Ukształtowanie się tej grupy społecznej wiązało się z rządami oligarchii magnackiej na przełomie XIII/XIV w., opartej na latyfundiach i sieci zamków - bądź przejętych od króla, bądź wzniesionych z własnej inicjatywy. Rzuca się w oczy zróżnicowanie położenia prawnego tej służebnej szlachty, zależnie od grupy, do której należeli, regionu, w którym zamieszkiwali, a także od podmiotu, któremu podlegali. To zróżnicowanie dotyczyło uprawnień do ziemi w zakresie dziedziczenia i obrotu (uprawnienia słabsze lub mocniejsze - za opłatą), danin i służb, sądownictwa itp. Szlachcice owi byli zobowiązani do wierności panu pod groźbą utraty ziemi, co przypomina normę dotyczącą prawdziwych szlachciców. Warunkowe posiadanie ziemi było rozpowszechnione także w majątkach kościelnych, gdzie szukano protekcji ${ }^{203}-\mathrm{w}$ XIII w. posiadacze takich służebnych nadań nazywali się conditionarii, nobiles/iobagiones ecclesiae, w XIV w. - praediales. Tych ostatnich niekiedy nazywano vassali. Warunkowe posiadanie ziemi było rozpowszechnione przede wszystkim na krańcach Królestwa - w Slawonii, nad dolnym Dunajem, w Górnych Węgrzech w następstwie organizowanego tam już w XIII w. osadnictwa wojskowego; tutaj służebni szlachcice nazywali się nobiles iobagiones, nobiles filli iobagionum, nobiles kneziales (Wołosi) ${ }^{204}$.

M. Rady zastanawia się nad podobieństwem węgierskiego systemu warunkowego posiadania ziemi do modelu feudalnego dzierżenia ziemi typu frankijskiego ${ }^{205}$. Za istotną cechę odmienną obu systemów uznaje to, że na Węgrzech, inaczej niż we Francji, „,warunkowy szlachcic” nie

199 M. Rady, op. cit., s. 38.

${ }^{200}$ Decreta Regni Hungariae. Gesetze und Verordnungen Ungarns 1301-1457, wyd. F. Döry i in., Budapest 1976, nr 11, s. 134.

${ }^{201}$ M. Rady, op. cit., s. 81 n.

202 Ibidem, s. 79 n.

${ }^{203}$ Ibidem, s. 82-84.

${ }^{204}$ Ibidem, s. 80, $85 \mathrm{nn}$.

${ }^{205}$ Ibidem, s. 94-95. 
mógł stać się prawdziwym szlachcicem. Wydaje się, że bardziej obiecujące byłoby porównanie w przyszłości węgierskich servientes z czeskimi/ morawskimi ministeriałami.

W dyskusji nad węgierskim feudalizmem zwraca się też uwagę na instytucję zwaną familiaritas. Byli familiares króla i familiares wielkich panów. Nie jest jasna relacja między servientes i familiares. Na przykład P. Engel reprezentuje pogląd, że pod określeniami servientes i familiares kryje się ta sama grupa społeczna służebników, z tym, że nazwę servientes stosowano w XIII, a nazwę familiares w XIV w. ${ }^{206} \mathrm{M}$. Rady oddziela servientes od familiares ${ }^{207}$. Zdaniem Damara Karbicia familiares to osoby ze ścisłej świty pana, na wysokich stanowiskach. Z jego badań wynika, że na Węgrzech od lat czterdziestych XIV w. termin serviens był wypierany przez rozpowszechniający się termin famulus, po połowie zaś XIV w. zaczął przyjmować się termin familiaris pod wpływem kontaktów z Andegawenami neapolitańskimi; jedynie w Chorwacji pojawił się on pół wieku wcześniej ${ }^{208}$.

W każdym razie terminem familiaris, famulus lub - u schyłku XV w. - servitor oznaczano kogoś, kto wstąpił na służbę u pana. Od 1298 r. obowiązywało prawo, że szlachcic swobodnie wybiera pana, któremu chce służyćc ${ }^{209}$. Służba była wynagradzana najczęściej w pieniądzu lub w naturze; wiadomo, że familiares starali się o dodatkowe dochody $\mathrm{z}$ handlu lub z kredytu ${ }^{210}$. Niekiedy wynagrodzeniem było nadanie ziemi. Taka donacja mogła oznaczać przekazanie własności użytkowej albo nadanie pleno iure, jednak niezależnie od tego określano je mianem beneficjum lub jako dzierżone „more et instar ceterorum liberorum servitorum, qui praediales solent nuncupari" ${ }^{111}$ - to sformułowanie wskazuje, że familiares przenikali się z grupą servitores. Nie jest jasne, w jakim zakresie beneficja mogły być interpretowane w kategoriach własności warunkowej. J. M. Bak zwraca uwagę na przypadki królewskiej konfirmacji prywatnych nadań ${ }^{212}$ - takie beneficja mogły mieć tym bardziej status

206 P. Engel, op. cit., s. 126.

${ }^{207}$ M. Rady, op. cit., s. $110 \mathrm{nn}$.

${ }^{208}$ D. Karbić, ,F Familiares of the Šubići”. Neapolitan influence on the origin of the institution of familiaritas in the medieval Hungary, w: La noblesse dans les territoires angevins à la fin du Moyen Âge, red. N. Coulet, J.-M. Matz, Rome 2000, s. 131-147.

209 „Item statuimus, quod nobiles seruire ualeant, quibuscunque uoluerint sua spontanea uoluntate", Rerum Hungaricarum Monumenta Arpadiana, wyd. L. Endlicher, Sangalli 1849, s. 637-638 (§ 27).

${ }^{210}$ E. Fügedi, The Elefánthy. The Hungarian Nobleman and His Kindred, Budapest 1998, s. 139.

${ }^{211}$ M. Rady, op. cit., s. 124.

${ }^{212}$ J. M. Bak, Feudalism in Hungary?, s. 212. 
majątków prawdziwej szlachty. Skądinąd wiadomo, że byli familiares szlachcice i familiares nieszlachcice ${ }^{213}$. Familiares niekiedy składali formalną przysięgę wierności, od około połowy XIII w. znane są pisemne umowy między panem i jego familiares specyfikujące zobowiązania obu stron, chociaż do późnego XV w. nie są one częste. Była to służba na żądanie. Niedochowanie wierności skutkowało, przynajmniej teoretycznie ${ }^{214}$, utratą beneficjum. Familiares wynagradzani w pieniądzu mogli posiadać swoje własne majątki; jeżeli takich nie mieli, dążyli do ich zakupu ${ }^{215}$. Służyli w oddziałach zbrojnych pana, pod jego chorągwią, ponadto pełnili funkcje na dworze oraz administracyjne lub sądowe w majątkach pana, a jeżeli pan był dostojnikiem terytorialnym - wojewodą, banem czy żupanen - byli współpracownikami takiego dygnitarza i pobierali za to wynagrodzenie $\mathrm{z}$ dochodów urzędu. Zapewne określenie takich pomocników dygnitarskich mianem familiares było bardziej dostojne niż predykat servientes.

Interpretacja feudalnego charakteru instytucji familiaritas jest sporna. J. Szücs pisał: „strukturze lennej w niepełnej wersji węgierskiej - familiaritas - brakowało głęboko zakorzenionego systemu instytucji, stabilności, a przede wszystkim - samego lenna" ${ }^{216}$.Zdaniem Erika Fügediego familiaritas przypominała zachodnią relację między feudalnym panem i wasalem, z tym, że węgierska odmiana tej relacji zachowywała większą elastyczność: ponieważ była pozbawiona aspektu rzeczowego, mogła być $\mathrm{w}$ dowolnym czasie zakończona ${ }^{217}$. $Z$ kolei $P$. Engel powiada, że familiaris nie był wasalem, ponieważ nie posiadał lenna; z panem łączyła go wyłącznie więź personalna ${ }^{218}$. M. Rady jest skłonny dopatrywać się podobieństwa między familiaritas i „nieprawym feudalizmem” (tj. służbą za wynagrodzenie w pieniądzu czy nadanie urzędu), ewentualnie między familiaritas i lennem-rentą. Natomiast jeżeli chodzi o nadania beneficjów, zachowuje ostrożność w traktowaniu tych donacji jako lenn, ponieważ familiaritas wyrażała się raczej poprzez wynagrodzenie pieniężne aniżeli nadawanie majątków ziemskich ${ }^{219}$.J. M. Bak też stawia pytanie, czy w przypadku

${ }^{213}$ P. Engel, op. cit., s. 127. Por. The Customary Law, II.23: „familiares aliquorum dominorum praelatorum aut baronum vel regni nobilium possessionatos et titulo vere nobilitatis fungentes”; II.23 § 2: „Ad solos autem rusticos vel rurales et iobagionalis conditionis homines atque familiares ignobiles attinet statutio quos proprii domini ipsorum terrestres et non officiales statuere ac in praesentiam iudicis sistere tenentur"; także II.51; II. 86 § 11; III. 26-27.

${ }^{214}$ J. M. Bak, Feudalism in Hungary?, s. 213.

${ }^{215}$ R. Fügedi, The Elefánthy, s. 139 n.

216 J. Szücs, op. cit., s. 65.

${ }^{217}$ E. Fügedi, Castle and Society, s. 78.

${ }^{218}$ P. Engel, op. cit., s. 127-128.

${ }^{219}$ M. Rady, op. cit., s. 77, 110 n., 126. 
familiares posiadających wynagrodzenie $\mathrm{w}$ formie beneficjum można mówić o wasalach i lennach. Raczej skłania się do odpowiedzi negatywnej, wskazując na swobodę podejmowania i opuszczania służby, zachowanie szlacheckiego statusu, pełną własność nadanego beneficjum, brak związku między nadaną ziemią a świadczonymi służbami ${ }^{220}$. Wreszcie G. Kristó mówi o adaptacji w instytucji familiaritas pewnych elementów zachodniej więzi wasalskiej i ukształtowaniu się węgierskiej wersji wasalstwa (charakteryzującej się mniejszym zakresem dokumentacji pisanej, słabiej zaznaczoną relacją wzajemności), która w zasadzie była odpowiednikiem zachodniego feudalizmu ${ }^{221}$.

W dyskusji nad węgierskim feudalizmem zwrócono baczną uwagę na tzw. honores. Kariera tej instytucji wiąże się z przeobrażeniami w organizacji zarządzania królestwem Węgier wraz z objęciem tronu przez władców z dynastii Andegawenów. Po pierwsze, było to wykreowanie nowej arystokracji oddanej dynastii, a po drugie, stworzenie sieci królewskich zamków, które władca nadawał arystokracji urzędniczej pro honore. Podobnie pro honore nadawał godności, przede wszystkim urząd żupana komitatu ${ }^{222}$. Honores były dzierżone ad beneplacitum regis przez pewien okres, bliżej nieustalony. Honores pozostawały własnością króla, posiadacz był użytkownikiem i czerpał dochody z majątków związanych z zamkiem. Żupanami pro honore byli przedstawiciele wielkiej szlachty, często czołowi urzędnicy dworu królewskiego (palatyn, najwyższy sędzia nadworny, podskarbi itp.) lub urzędnicy terytorialni (żupani, ban Slawonii, wojewoda Siedmiogrodu). Posiadacze honores, administrując nimi, opierali się na swoich familiares, jednak w literaturze jest kwestią sporną, czy kasztelanów poszczególnych zamków mianował król czy arystokraci - żupani pro honore. Za królem opowiada się E. Fügedi ${ }^{223}$, za arystokratami - P. Engel ${ }^{224}$.

P. Engel zwraca uwagę na językowe ekwiwalenty: honor = becsület, becsü = feudum. Proponuje widzieć $\mathrm{w}$ honores lenna-urzędy nadawane wielkim lennikom Królestwa. Podkreśla, że była to feudalność funkcjonalna, a nie strukturalna: „Formy feudalne były ograniczone do majątków nadawanych pro honore i nie prowadziły do powstania prawdziwych lenn"225. Zupełnie inny punkt widzenia prezentuje E. Fügedi, który

${ }^{220}$ J. M. Bak, Feudalism in Hungary?, s. 215.

${ }^{221}$ G. Kristó, op. cit., s. 157, 170.

${ }_{222}$ Zob. S. A. Sroka, Andegaweńska reorganizacja Węgier $w$ świetle nowszych badań, $\mathrm{KH}$ 103, 1996, 2, s. 23 nn.

${ }^{223}$ E. Fügedi, Castle and Society, s. 105 n.; zob. S. A. Sroka, op. cit., s. 28 n.

${ }^{224}$ P. Engel, op. cit., s. 151 nn., 213 n.; idem, Honor, castrum, comitatus. Studies in the Government System of the Angevin Kingdom, „Quaestiones Medii Aevi Novae” 1, 1996, s. 92 n.

225 „Feudal forms were restricted to estates conferred pro honore and did not lead to the emergence of genuine fiefs", P. Engel, Honor, castrum, comitatus, s. 92. 
powiada, że nie tylko większość zamków była w ręku kasztelanów mianowanych przez króla, lecz ponadto posiadacze honorów, którymi zarządzali w imieniu króla, otrzymywali tylko część dochodów. Nie może być mowy o utożsamianiu honoru z lennem, ponieważ średniowieczne Węgry lenna nie znały ${ }^{226}$. M. Rady wspomina przypadek z połowy XV w., że określenie „in honore” zostało przetłumaczone jako „in feudum”227. Przy wszystkich zastrzeżeniach dochodzi do wniosku, że Węgry mogły znać lenno pod terminem honor; to mógł być odpowiednik lenn-urzędów ${ }^{228}$. Skądinąd wiadomo, że przy nadawaniu honores nie składano przysiąg i hołdów poza krótkim okresem w końcu XIII w. W każdym razie według owego autora można by widzieć pewną feudalną hierarchię na Węgrzech, złożoną z honores i familiaritas. J. M. Bak natomiast nie jest przekonany co do kwalifikacji honorów jako lenna-urzędu. Zwraca uwagę na istotną okoliczność, mianowicie proces transformacji komitatów od składnika królewskiej domeny do korporacji miejscowej szlachty ${ }^{229}$.

Wydaje się, że badania nad węgierskimi honorami posuną się do przo$\mathrm{du}$, jeżeli będą podjęte nowe studia analityczne oraz zostanie zastosowana metoda porównawcza. Tak jak przy problematyce familiares odwoływano się do angielskiego konceptu nieprawego feudalizmu, również w badaniach instytucji honores (i grupy społecznej familiares) obiecująco rysują się perspektywy wykorzystania dorobku historiografii angielskiej dotyczącego honores w średniowiecznej Anglii ${ }^{230}$. Kolejna kwestia to recepcja kultury rycerskiej na Węgrzech XIV-XV w.; bez uwzględnienia tej problematyki badania feudalizmu nie da się prowadzić. Rozumie to dobrze M. Rady ${ }^{231}$. Zdaniem J. Szücsa „Z powodu braku dworów feudalnych i środowiska rycerskiego, [- - ] [a także - M.D.] wykształconych form feudalizmu [- - ] w historii Węgier było niewiele miejsca na jednolitą i autonomiczną

226 S. A. Sroka, op. cit., s. 28 n.

${ }^{227}$ M. Rady, op. cit., s. 142.

${ }^{228}$ Ibidem, s. 133, 143 i por. s. 181 n.: „Hungary may, therefore, have known the fief under the different name of the honor".

${ }^{229}$ „The «county» at that time was in transition from its original meaning as a territorial part of the extensive royal domain [- ] towards a corporation of nobles of a district (which itself grew out of the «royal county»). The ispán was to be the king's representative in the particular district, administering justice and finances in concert with elected officials of the noble corporation. The king was less and less interested in these activities", J. M. Bak, Feudalism in Hungary?, s. 216. W sprawie komitatów jako „body of nobility” także E. Fügedi, The Elefánthy, s. 140; P. Engel, G. Kristó, A. Kubinyi, Histoire de la Hongrie médiévale, t. 2: Des Angevins aux Habsbourgs, Rennes 2008, s. 83 nn.

${ }^{230}$ Zob. przeglądowy artykuł: P. Coss, From Feudalism to Bastard Feudalism, w: Die Gegenwart des Feudalismus, s. 79-107.

${ }^{231}$ M. Rady, op. cit., s. 126-131 (podrozdział: „The royal aula and the ethos of chivalry"). 
kulturę rycerską. Bardzo szybko oraz niezbyt proporcjonalnie rozrosła się natomiast warstwa szlachecka" ${ }^{232}$. W. Iwańczak wskazuje, że na Węgrzech dopiero u schyłku średniowiecza zaznacza się zaciekawienie kulturą rycersko-dworską ${ }^{233}$. Z kolei P. Engel wyraża opinię, że kultura rycersko-dworska była swoistym pokostem, pod którym skrywała się bliższa szlachcie kultura tradycyjna ${ }^{234}$.

Tak czy inaczej, powstaje kwestia urzędniczych podstaw arystokracji węgierskiej późnego średniowiecza; czy i w jakiej mierze hierarchia urzędów miała pierwszeństwo przed hierarchią pasa rycerskiego.

\section{VII}

Na początku niniejszego artykułu przytoczyliśmy pogląd J. M. Baka, że w Europie Środkowo-Wschodniej (w przyjętym przez nas znaczeniu) feudalizmu nie było. Co najwyżej w Czechach/na Morawach istniały pewne elementy prawa lennego przejęte z Niemiec ${ }^{235}$. W zasadzie można $\mathrm{z}$ tym poglądem się zgodzić, upominając się jednocześnie o śląsk. Być może istniał jednak jakiś quasi-feudalizm na Węgrzech w XIV w. Mniej przekonujący jest inny pogląd tego badacza, że drobni szlachcice w Polsce czy na Węgrzech, zależni, ale osobiście uprzywilejowani, przypominali ministeriałów z krajów niemieckich ${ }^{236}$. Recepcji ministerialitetu we właściwym sensie tego słowa doszukiwalibyśmy się raczej w Czechach/na Morawach w końcu XII i w XIII w. Być może sui generis ministerialitet istniał na Węgrzech w XII w. Natomiast na razie nie da się nic powiedzieć o ministerialitecie w Polsce pełnego średniowiecza.

Powstaje pytanie o przyczyny recepcji lub braku recepcji feudalizmu w krajach Europy Środkowo-Wschodniej. Nie da się sensownie odpowiedzieć na to pytanie, abstrahując od genezy feudalizmu w czołowych krajach Europy Zachodniej.

Przypomnijmy, że według S. Reynolds lenno ukształtowało się na Zachodzie na dobre dopiero w XIII w. Inicjatorami rozwoju prawa własności

${ }^{232}$ J. Szücs, op. cit., s. 65-66.

${ }^{233}$ W. Iwańczak, Rola i znaczenie dwóch kręgów cywilizacyjnych, s. 103-104; por. także A. Kubinyi, Alltag und Fest am ungarischen Königshof der Jagellonen. 1490-1526, w: idem, König und Volk im spätmittelalterlichen Ungarn, Herne 1998, s. 184-206.

${ }^{234}$ "The members of the court may have lived according to chivalrous ceremonies, and they certainly had a markedly aristocratic view of the world; but they remained essentially Hungarian noblemen, belonging to an archaic world that was inextricably intertwined with pagan and patriarchal traditions", P. Engel, The Realm, s. 147.

235 J. M. Bak, Probleme einer vergleichenden Betrachtung mittelalterlicher Eliten in Ostmitteleuropa, s. 60.

${ }^{236}$ Ibidem, s. 60, przyp. 45. 
polegającego na pojawieniu się, obok dotychczas dominującej własności pełnej, także własności warunkowej byli władcy, którzy lenno postrzegali jako dogodne narzędzie służące do politycznego podporządkowania klasy rycerskiej. Dlatego w niewielkim stopniu ograniczano prawa majątkowe rycerzy-lenników, nacisk był położony raczej na artykulację relacji podległości poprzez wykorzystanie środków komunikacji symbolicznej. Formalizacja relacji społecznych znajdowała odzwierciedlenie w hierarchii feudalnej. Zasady nowego prawa opracowali prawnicy po uniwersytetach, odpowiedzialnym zaś za ich wprowadzenie w życie był fachowy aparat urzędniczy - fundament modernizującej się monarchii pełnego średniowiecza. W tle tych przemian był ogólny rozwój Europy Zachodniej w XII-XIII w. wyrażający się w przyroście liczby ludności, komercjalizacji gospodarki oraz ekspansji pisma.

Ostatnio Charles West dokonał rewizji ustaleń S. Reynolds ${ }^{237}$. Proponuje interpretować feudalizm jako przejaw procesu formalizacji relacji społecznych, zapoczątkowanego wskutek reform podjętych jeszcze w czasach karolińskich. Rozpad imperium karolińskiego nie powstrzymał tego procesu. Formalizacja relacji społecznych objęła też własność. Komplikujące się relacje władcze znajdowały odzwierciedlenie w coraz bardziej złożonej hierarchii praw własności. Pojawienie się lenna nie było tylko przejawem politycznej kontroli nad posiadaniem ziemi, ale oznaczało rzeczywistą, głęboką zmianę w prawie własności. W lennie, hołdzie, przysiędze wyrażała się precyzja myślenia o relacjach społecznych z tendencją do urzeczowienia tych relacji. Formalizacja relacji społecznych dokonywała się stopniowo, bez udziału profesjonalnych prawników. Rozwój Europy Zachodniej w pełnym średniowieczu nie miał istotnego znaczenia dla powstania feudalizmu.

Przy całej odmienności poglądów S. Reynolds i Ch. Westa wspólne dla obojga autorów jest traktowanie ośrodków władzy (król, hrabia itp.) jako inicjatorów przemian politycznych i społecznych prowadzących do feudalizmu. W takim ujęciu feudalizm kształtuje się w wyniku impulsów idących „od góry”, od „państwa”. Jest to o tyle nowe podejście, że z reguły postrzegano feudalizm (kontynentalny) jako rezultat działań politycznych podejmowanych przez czynniki społeczne „od dołu” i skierowanych przeciw „państwu”.

Co prawda $\mathrm{Ch}$. West postuluje zerwanie z patrzeniem na feudalizm w perspektywie losów średniowiecznego „państwa” ${ }^{238}$,jednak pisze o feudalizmie w kontekście formalizacji więzi społecznych wywołanej przez

${ }^{237}$ Ch. West, op. cit., passim.

238 „Instead of tracking how feudalism worked for or against a state, and without denying the importance of communities, it has argued that relations amongst the elite became mediated through signs, practices and concepts that imbued these 
państwo karolińskie. Jest w takim podejściu pewna niekonsekwencja. Inna sprawa, że w praktyce badawczej nie zawsze udaje się urzeczywistnić wyznawane poglądy teoretyczne, chociażby z racji wykorzystywanej z konieczności literatury przedmiotu. W każdym bądź razie propozycja Ch. Westa, aby myślenie o feudalizmie oswobodzić od myślenia o państwie, zasługuje na uznanie. Natomiast traktowanie feudalizmu jako rezultatu kumulatywnych zmian zapoczątkowanych działaniami Karola Wielkiego nie trafia nam do przekonania.

W niniejszym artykule proponujemy, aby badania nad feudalizmem ugruntować w wybranych teoriach socjologicznych, przede wszystkim w teorii wymiany społecznej oraz w teorii społecznych granic wzrostu gospodarczego. Odmiennie bowiem niż Ch. West, a raczej w duchu poglądów S. Reynolds, jesteśmy skłonni łączyć genezę feudalizmu z okresem wzrostu Europy w XII-XIII w. Jako że teoretyczne aspekty problematyki feudalizmu zostały tutaj jedynie zasygnalizowane, ujęcie integralne trzeba odłożyć na przyszłość.

W świetle przyjętych założeń teoretycznych w centrum uwagi postawić należy pojawienie się warunkowej własności ziemi. Wypada zgodzić się z Ch. Westem, że przejście od alodium do lenna było niezwykle głęboką zmianą w prawie własności. Jednak taka zmiana mogła być pożądana przez posiadaczy alodiów, więcej nawet, zależna własność ziemi mogła być uważana przez nich za najlepsze prawo własności. Wraz z pojawieniem się lenna zachodził w obrębie rycerstwa proces rozkładu zbiorowości krewniaczej na rzecz nowej zbiorowości - feudalnej. O ile zbiorowość krewniacza koncentrowała się na współpracy, o tyle zbiorowość feudalna - na współzawodnictwie. W ramach teorii wymiany społecznej możliwa jest konceptualizacja motywacji, instytucji, norm oraz sposobów komunikacji (kultury) w związku z transformacją feudalną.

W większości krajów Europy Środkowo-Wschodniej miejscowe rycerstwo stawiało posiadanie ziemi na pełną własność wyżej niż jej posiadanie na własność warunkową. Wolno wiązać to zjawisko z faktem, że wzrost gospodarczy w tej części Europy w pełnym średniowieczu miał dużo mniejsze tempo, wielkość oraz intensywność niż w czołowych krajach Zachodu. Sprzężone z tym wzrostem procesy wymiany społecznej w obrębie rycerstwa nie zdołały doprowadzić do ukształtowania się nowych zbiorowości, którym byłby bliski etos współzawodnictwa.

relations with ever clearer and less ambivalent content, often but not always or necessarily related to landholding", ibidem, s. 222. 


\section{Did Feudalism Exist in East-Central Europe during the Middle Ages?}

The existence of feudalism based on the fief and or land dominion in the kingdoms of Poland, Bohemia and Hungary during the Middle Ages remains debatable. In turn, the destruction of the heretofore model of feudalism in Western Europe resulted in a negation of the division of Europe into feudal and non-feudal.

There is no need, however, to resign from the concept of feudalism as an analytical category. The foundation of feudalism consisted of the land fief, which emerged in connection with general growth of Western Europe in the High Middle Ages. The concept of social scarcity explains a phenomenon characteristic for periods of growth, i.e. social control of access to property envisaged as status symbols. In the world of European knights during the High Middle Ages social scarcity was represented by land. Access to it was controlled with the assistance of feudal law. The rank of the vassals was reinforced by "cultural capital" specific for them and concentrated on rivalry and maximum efforts.

It is possible to speak about the reception of feudal law transferred from Germany to Moravia, Bohemia, and Silesia. Quite possibly, some sort of quasi-feudalism existed in Hungary. In Bohemia and Moravia, starting with the twelfth-thirteenth century, there emerged a rather conspicuous group of ministeriales; a similar situation also occurred in Silesia. Ministeriales could have also existed in twelfth-century Hungary. In Poland (with the exception of Silesia) there are no noticeable traces of ministeriales and certain elements of feudal law were probably used only to a slight extent.

In the majority of East-Central Europe knights preferred full land ownership to conditional ownership. Processes of social exchange in connection with relatively weak growth during the High Middle Ages were incapable of moulding new communities sharing the feudal ethos of rivalry and competition.

Translated by Aleksandra Rodzińska-Chojnowska 